\title{
Cascading predation effects of Daphnia and copepods on microbial food web components
}

\author{
ECKART ZÖLLNER*, BARBARA SANTER*, MAARTEN BOERSMA* ${ }^{\ddagger}$ HANS-GEORG HOPPE ${ }^{\dagger}$ \\ AND KLAUS JÜRGENS*,§ \\ *Max Planck Institute for Limnology, Plön, Germany \\ IInstitute for Marine Research, Kiel, Germany \\ $\ddagger$ Alfred Wegener Institute for Polar and Marine Research, Biologische Anstalt Helgoland (BAH), Helgoland, Germany \\ §Present address: Baltic Sea Research Institute, Warnemünde, Germany
}

\section{SUMMARY}

1. We performed a mesocosm experiment to investigate the structuring and cascading effects of two predominant crustacean mesozooplankton groups on microbial food web components. The natural summer plankton community of a mesotrophic lake was exposed to density gradients of Daphnia and copepods. Regression analysis was used to reveal topdown impacts of mesozooplankton on protists and bacteria after days 9 and 15 .

2. Selective grazing by copepods caused a clear trophic cascade via ciliates to nanoplankton. Medium-sized (20-40 $\mu \mathrm{m}$ ) ciliates (mainly Oligotrichida) were particularly negatively affected by copepods whereas nanociliates (mainly Prostomatida) became more abundant. Phototrophic and heterotrophic nanoflagellates increased significantly with increasing copepod biomass, which we interpret as an indirect response to reduced grazing pressure from the medium-sized ciliates.

3. In Daphnia-treatments, ciliates of all size classes as well as nanoflagellates were reduced directly but the overall predation effect became most strongly visible after 15 days at higher Daphnia biomass.

4. The response of bacterioplankton involved only modest changes in bacterial biomass and cell-size distribution along the zooplankton gradients. Increasing zooplankton biomass resulted either in a reduction (with Daphnia) or in an increase (with copepods) of bacterial biovolume, activity and production. Patterns of bacterial diversity, as measured by polymerase chain reaction-denaturing gradient gel electrophoresis (PCR-DGGE), showed no distinct grouping after 9 days, whereas a clear treatment-coupled similarity clustering occurred after 15 days.

5. The experiment demonstrated that zooplankton-mediated predatory interactions cascade down to the bacterial level, but also revealed that changes occurred rather slowly in this summer plankton community and were most pronounced with respect to bacterial activity and composition.

Keywords: bacteria, mesozooplankton, protists, trophic cascade

Correspondence: Eckart Zöllner, Max Planck Institute for Limnology, PO Box 165, 24302 Plön, Germany.

E-mail: zoellner@mpil-ploen.mpg.de

\section{Introduction}

Planktonic bacteria are regulated by the availability of inorganic and organic nutrients ('bottom-up-control'), by bacterivorous protists ('top-down-control'), and by viral lysis (Thingstad \& Lignell, 1997). In recent years it has become evident that the classical grazer food 
chain and the microbial food web are linked by several direct and indirect interactions. Most planktonic protists are within the prey size spectrum of different metazooplankton groups (Carrick et al., 1991; Arndt, 1993; Sanders \& Wickham, 1993). Moreover, cladocerans, especially Daphnia spp., can sometimes replace protozoans as the major bacterial consumer in freshwater lakes (Pace, McManus \& Findlay, 1990; Jürgens, 1994). Because bacteria mediate key pathways in global biogeochemical cycles we should assume that factors controlling biomass, production and turnover rates of microorganisms are also factors that regulate key functions at the ecosystem level (Cotner \& Biddanda, 2002).

Grazing by different mesozooplankton groups (zooplankton with a body size of $0.2-2 \mathrm{~mm}$ ), consisting of crustacean taxa like cladocerans and copepods, is an important factor shaping the autotrophic and heterotrophic communities at lower trophic levels. In particular, filter-feeding cladocerans (e.g. Daphnia spp.) can cause order-of-magnitude biomass reductions in phytoplankton (Lampert et al., 1986) and both can affect phytoplankton species composition (Vanni \& Temte, 1990; Sarnelle, 1993). Although a wide overlap in the food spectrum of cladocerans and copepods is generally found, the minimal sizes for food particles ingested by most copepods are clearly larger than for cladocerans (Gliwicz, 1980) and copepods can select easily between food items (DeMott, 1988). Consequently, these mesozooplankton guilds are expected to exert different predation impacts on heterotrophic microorganisms. Although both copepods and cladocerans occur in most lakes, there have been only a few direct comparisons of their consumer effects on microbial food webs (Wickham, 1998; Burns \& Schallenberg, 2001a; Yoshida et al., 2001). Because of the overwhelming predation effects of large-sized cladocerans, particularly daphnids, Daphnia-based studies constitute the basis of most current models of metazoan effects on microorganisms in freshwater systems (see reviews in Porter et al., 1988; Riemann \& Christoffersen, 1993; Jürgens, 1994). Being a relatively unselective filter feeder, Daphnia can exert strong top-down impact on phytoplankton as well as on the protozoan and bacterial assemblages. In contrast, relatively little is known about the potential cascading trophic interactions proceeding, via direct and indirect effects, from copepods to bacteria. The selective predatory impact of cyclopoid and calanoid copepods has been demonstrated with ciliates as prey (e.g. Burns \& Gilbert, 1993; Wickham, 1995), but few investigations have also examined possible cascading trophic effects from copepod-dominated zooplankton down to the bacterial community (e.g. Burns \& Schallenberg, 1996, 1998, 2001b; Yoshida et al., 2001).

However, whereas experimental manipulations of crustacean zooplankton generally resulted in clear predation-mediated effects on planktonic protists, changes in bacterial biomass have only rarely been detected (Pace \& Funke, 1991; Wickham, 1998; Adrian, Wickham \& Butler, 2001) and studies in oligo- to mesotrophic lakes generated somewhat conflicting results. This is possibly because of the importance of the actual zooplankton densities used in the experiments and also due to the fact that previous studies have focused almost exclusively on the numerical response of the bacterioplankton to the different zooplankton treatments. Therefore, in this mesocosm study we set out to assess and refine the differential effects of cladocerans and copepods on microbial food web components. Other responses of the plankton community, derived from the same study, have been reported by Sommer et al. (2001, 2003a,b). In this mesocosm experiment, we used gradients of realistic cladoceran and copepod densities in order to account for zooplankton density effects. We measured the response of bacterial biomass, but we also considered changes in bacterial activity, morphology and diversity.

\section{Methods}

\section{Experimental design}

The mesocosm experiment (7-28 August 2000) was performed in Schöhsee, a mesotrophic lake in northern Germany (mean depth $13 \mathrm{~m}$, maximum depth $30 \mathrm{~m}$, area $82 \mathrm{ha}$ ). Natural phytoplankton and microzooplankton were exposed to density gradients of cladocerans (Daphnia hyalina $\times$ galeata) and copepods (consisting of approximately $50 \%$ Eudiaptomus spp. and $50 \%$ copepodite stages of cyclopoid copepods). Twenty-four transparent polyethylene bags $\left(2.5 \mathrm{~m}^{3}\right.$ in volume, $3.2 \mathrm{~m}$ in depth) were filled with lake water from which mesozooplankton was removed by sieving through $50-\mu \mathrm{m}$ plankton gauze. To ensure a balanced total $\mathrm{N}$ : total $\mathrm{P}$ ratio (Redfield ratio $16: 1$, 
here $34.86 \mu \mathrm{M} \mathrm{N}, 2.18 \mu \mathrm{MP}$ ), used for studying the impact of both zooplankton groups on the stoichiometry of $\mathrm{N}$ and $\mathrm{P}$ recycling (Sommer et al., 2003b), the bags were fertilised by adding phosphorus $(1.53 \mu \mathrm{M}$ $\mathrm{NaH}_{2} \mathrm{PO}_{4}$ ).

After 2 days, cladocerans from stock cultures of the Max Planck Institute for Limnology (Plön, Germany) were added to the cladoceran treatments ('dap') to achieve approximately logarithmically scaled seeding densities of 1.25, 2.5, 5, 10, 20 and 40 individuals per litre. More details on size structure and pretreatment of mesozooplankton can be found in Sommer et al. (2001, 2003b). Copepods derived from wild catches from the same lake 2 days prior to the experiment were added in logarithmically scaled seeding densities of approximately 5, 10, 20, 40, 80 and 160 individuals per litre to the copepod treatments ('cop'). Apart from the lowest density enclosures (dap 1.25, cop 5), all mesozooplankton seeding density treatments were replicated. Two mesocosms without the addition of zooplankton served as controls. For data evaluation we used the actual zooplankton biomass in each bag, so that each gradient consisted of 13 data points.

Throughout the course of the experiment, we measured chlorophyll $a$ daily, determined zooplankton densities every 3-4 days, and used these data to select appropriate dates for our in-depth analysis of the microbial communities. Days 9 and 15 were chosen according to the development of the zooplankton gradient: after 9 days with rather low numbers and a narrow biomass range, and after 15 days with a wider range and higher maximal biomass values. On days 9 and 15 , we determined the concentrations of protists and bacteria, evaluated bacterial diversity using denaturing gradient gel electrophoresis (DGGE), and measured bacterial activity using ${ }^{3} \mathrm{H}$-thymidine and ${ }^{3} \mathrm{H}$-leucine incorporation as well as exoenzyme (protease) hydrolysis measurements (see below).

\section{Sampling and enumeration of organisms}

Sampling of the mesocosms for microbial components (picoplankton, protozoans) was done using a $10 \mathrm{~L}$ can after gently mixing the water column up to $2 \mathrm{~m}$ depth with a Secchi disc. Zooplankton sampling was carried out every third to fourth day by towing a $50 \mu \mathrm{m}$-mesh plankton net with a reducing cone diameter of $9 \mathrm{~cm}$ from a depth of $3 \mathrm{~m}$ to the surface. Zooplankton was fixed with formaldehyde ( $4 \%$ final concentration) and counted and sized under a dissecting microscope. Zooplankton biomass was calculated from length measurements using published length-biomass regressions (Bottrell et al., 1976). Chlorophyll a measurements were performed with a submersible fluorometer (Fluoroprobe, BBE Moldaenke, Kiel, Germany) that is able to register in vivo fluorescence of phytoplankton (e.g. Beutler et al., 2002).

Ciliates were fixed with acid Lugol's solution (final concentration $1 \%$ ) and counted and sized in sedimenting chambers with an inverted microscope (Zeiss Axiovert 35). Ciliate groups were distinguished according to Foissner \& Berger (1996). Three size classes of ciliates were differentiated (largest dimension): ciliates $<20 \mu \mathrm{m}$ (referred to as nanociliates), $20-40 \mu \mathrm{m}$ and $>40 \mu \mathrm{m}$. Samples for enumeration of bacteria, of chroococcal cyanobacteria (autotrophic picoplankton, APP, mainly Synechococcus-like cells) and nanoflagellates were preserved in formalin (final concentration $2 \%$ ) and stored at $4{ }^{\circ} \mathrm{C}$ until further processing (usually within the next $24 \mathrm{~h}$ ). Subsamples were filtered onto black polycarbonate filters, $1 \mathrm{~mL}$ for counting of picoplankton $(25 \mathrm{~mm}$, pore size $0.2 \mu \mathrm{m}$ ), $5 \mathrm{~mL}$ for enumeration of nanoflagellates $(25 \mathrm{~mm}$, pore size $0.8 \mu \mathrm{m}$ ), and stained with 4',6-Diamidno-2-Phenylindole (DAPI) (Sigma-Aldrich Chemie $\mathrm{GmbH}$, Steinheim, Germany) at a final concentration of $4 \mu \mathrm{g} \mathrm{mL}{ }^{-1}$ and stored at $-20{ }^{\circ} \mathrm{C}$ until microscopical enumeration. DAPI preparations were analysed in an epifluorescence microscope (Zeiss Axiophot, Carl Zeiss Jena $\mathrm{GmbH}$, Jena, Germany) at $1250 \times$ magnification. APP were enumerated under green light excitation. Heterotrophic flagellates were distinguished from phototrophic flagellates (auto and mixotrophic nanoflagellates, AMNF) by checking for chlorophyll $a$ autofluorescence under blue light excitation.

Bacterial abundances and biovolumes were determined using an automated imaging system (analySIS 3.0, Soft Imaging Systems GmbH, Münster, Germany). Epifluorescence images (10 per sample with a total of $500-700$ cells) were digitised and automatically processed including filtering, threshold setting and binarisation as described in Massana et al. (1997). Cell volumes $(V)$ were calculated according to:

$$
V=\frac{8.5 \times A^{2.5}}{P^{2}},
$$

where $A$ is the area and $P$ the perimeter of the cell (Björnsen, 1986). 


\section{Bacterial diversity}

For the extraction of bacterial DNA, $100 \mathrm{~mL}$ of samples fixed with formalin for up to $12 \mathrm{~h}$ were filtered onto Durapore filters $(47 \mathrm{~mm}$, pore size $0.2 \mu \mathrm{m}$, Millipore) and stored in Petri dishes at $-80{ }^{\circ} \mathrm{C}$ until DNA extraction. Extraction of DNA followed the protocol reported by Schauer, Massana \& Pedros-Alio (2000), which includes the addition of lysozyme, sodium dodecyl sulfate and proteinase K, followed by extraction with phenol-chloroformisoamyl alcohol (25:24:1, pH 8) and chloroformisoamyl alcohol (24:1) and subsequent concentration and rinsing steps. After quantifying spectrofluorometrically the extracted microbial DNA with a Hoechst fluorescence assay (Paul \& Myers, 1982), 1-8 ng of DNA was used as template for polymerase chain reaction (PCR) amplification of bacterial 16S rDNA. The reactions ( $50 \mu \mathrm{L}$ volume) contained $200 \mu \mathrm{M}$ of each of the desoxynucleoside triphosphates, $0.3 \mu \mathrm{M}$ of each of the primers, $1.5 \mathrm{~mm} \mathrm{MgCl}_{2}$, 10x PCR buffer and 1.25 U Taq DNA polymerase (Biozym Diagnostik $\mathrm{GmbH}$, Hess Oldendorf, Germany). We used the bacterial specific primer 358f, with a 40-bp GC clamp, and the universal primer 907r, which amplifies a 550bp DNA fragment of bacterial 16S rDNA (Muyzer et al., 1998). The PCR was performed with an iCycler (Biorad Laboratories $\mathrm{GmbH}$, München, Germany) thermal cycler using the following program: initial denaturation at $94{ }^{\circ} \mathrm{C}$ for $5 \mathrm{~min}$; 10 touchdown cycles of denaturation (at $94{ }^{\circ} \mathrm{C}$ for $1 \mathrm{~min}$ ), annealing (at 65$55^{\circ} \mathrm{C}$ for $1 \mathrm{~min}$, decreasing $1{ }^{\circ} \mathrm{C}$ each cycle) and extension (at $72{ }^{\circ} \mathrm{C}$ for $3 \mathrm{~min}$ ); 20 standard cycles of denaturation (at $94{ }^{\circ} \mathrm{C}$ for $1 \mathrm{~min}$ ), annealing (at $55^{\circ} \mathrm{C}$ for $1 \mathrm{~min}$ ) and extension (at $72{ }^{\circ} \mathrm{C}$ for $3 \mathrm{~min}$ ) and a final extension at $72{ }^{\circ} \mathrm{C}$ for $7 \mathrm{~min}$. PCR products were verified by agarose gel electrophoresis with a standard in the gel (Low DNA Mass Ladder, Gibco BRL) and quantified again (see above).

Denaturing gradient gel electrophoresis was carried out with a D-Code system (Biorad) as described in Muyzer et al. (1998). A 6\% polyacrylamide gel with a gradient of a DNA-denaturing agent was cast by mixing solutions of 40 and $80 \%$ denaturant agent (100\% denaturant agent is $7 \mathrm{M}$ urea and $40 \%$ deionised formamide) with a gradient former (Biorad). Equal amounts of PCR product were loaded and the gel was run at $100 \mathrm{~V}$ for $16 \mathrm{~h}$ at $60^{\circ} \mathrm{C}$ in $1 \times$ TAE buffer (40 mM Tris, $\mathrm{pH} 7.4,20 \mathrm{~mm}$ sodium acetate, $1 \mathrm{~mm}$ ethylenediaminetetraacetic acid, EDTA). The gel was stained with the nucleic acid stain SYBR Gold (Molecular Probes) for $30 \mathrm{~min}$, rinsed with Milli-Q water, removed from the glass plate to a UV-transparent gel scoop and visualised with UV. By using the software GeneSnap 4.00. (SynGene, Cambridge, England, U.K.) high-resolution images were saved as computer files. To obtain quantitative information from DGGE fingerprints, digitised DGGE images were analysed with the software GeneTools 3.00.22 (SynGene, Cambridge, England, U.K.). The software performs a density profile through each lane, detects the bands (regarded as operational taxonomic units, OTUs) and calculates the relative contribution of each band to the total band signal in the lane after applying a rolling disk as background subtraction. Bands with a relative intensity of $<0.2 \%$ of the total intensity of the lane were disregarded. The bands occupying the same position in the different lanes of the gel were identified by visual inspection. A matrix was compiled based upon the presence or absence of individual bands in each lane and the relative contribution of the band to the total band signal.

\section{Bacterial production and physiological activity}

On days 8 and 15, production of heterotrophic bacterioplankton was measured as ${ }^{3} \mathrm{H}$-thymidine incorporation into cold-TCA-insoluble material following a slightly modified protocol given by Bell (1993). ${ }^{3} \mathrm{H}$-thymidine (specific activity 87 or $90 \mathrm{Ci} / \mathrm{mmol}$, Amersham Biosciences Europe GmbH, Freiburg, Germany) was added at a saturating concentration (40 $\mathrm{nmol} \mathrm{L}{ }^{-1}$ final concentration). As a measure of metabolic activity and protein synthesis, incorporation of ${ }^{3} \mathrm{H}$-labelled leucine $\left(80 \mathrm{nmol} \mathrm{L}^{-1}\right.$ final concentration, $145 \mathrm{Ci} / \mathrm{mmol}$, Amersham) into cold-TCA-insoluble material was registered according to a slightly modified protocol described by Kirchman (1993). All samples were incubated for $1 \mathrm{~h}$ at in situ-temperature. Formalin-killed controls were used to correct for background absorption of radioactivity. For an estimation of bacterial doubling times we used the empirical conversion factors of $2 \times 10^{18}$ cells mol $^{-1}$ thymidine (Smits \& Riemann, 1988) and $0.18 \times 10^{18}{\text { cells } \mathrm{mol}^{-1}}^{-1}$ leucine (Ducklow, Kirchman \& Quinby, 1992).

To determine shifts in size distribution of bacterial activity, fractionated ${ }^{3} \mathrm{H}$-thymidine uptake was measured for selected enclosures on days 10 and 15 . 
Samples were incubated with ${ }^{3} \mathrm{H}$-thymidine $\left(20 \mathrm{nmol} \mathrm{L}{ }^{-1}\right.$ final concentration) for $1 \mathrm{~h}$ at in situtemperature. Subsamples were filtered with low pressure (gravity filtration) on $0.2,1$ and $3-\mu \mathrm{m}$ filters. Filters were rinsed with MQ-water only, to avoid disruption of cells, and were then put into scintillation cocktail and radioassayed.

Enzymatic protease hydrolysis was determined on days 8 and 15 by using leucine-methylcoumarinylamide (Leu-MCA) as a fluorogenic substrate analogue (Hoppe, 1993). The concentrations of added substrates were $1 \mu \mathrm{mol} \mathrm{L}{ }^{-1}$ for determining the turnover rate (TR) and $250 \mu \mathrm{mol} \mathrm{L}{ }^{-1}$ for determining the maximal velocity of hydrolysis $\left(V_{\max }\right)$. These concentrations were successfully applied in gradients of eutrophication (Hoppe, Giesenhagen \& Gocke, 1998). This approach was adopted from the two concentration methods used in the determination of turnover time and $V_{\max }$ in substrate uptake studies (Gocke, 1977). Samples were incubated in microtiterplates (four parallels for each concentration). Readings of fluorescence at the beginning and end of the incubation period $(3 \mathrm{~h})$ were made in an automatic Titertek Fluoroskan II fluorometer. The factor necessary for converting fluorescence units to units of $\mu \mathrm{mol} \mathrm{L} \mathrm{L}^{-1} \mathrm{~h}^{-1}$ ( $\mu \mathrm{mol}$ of substrate hydrolysed per unit of volume and time) was derived from standard additions of the fluorescing compound Amidomethylcoumarin (AMC).

\section{Statistical analysis}

The binary matrix (presence/absence of bands) obtained from the DGGE gel was used to calculate a distance matrix using Euclidean distances (root-meansquared differences). A dendrogram comparing samples was obtained by Unweighted Pair-Group Method with Arithmetic averages (UPGMA) in cluster analysis. To analyse the effects of mesozooplankton on the abundances, biovolumes and incorporation rates of pico- and nanoplankton, regression analyses were performed. As the dependent parameters at the sampling dates are a time integrated response of the period prior to sampling, time averaged zooplankton densities (geometric means of day 6 and 9 for day 9 , and of day 13 and 16 for day 15) were multiplied with a mean biomass value for each enclosure obtained from length measurements (see above). Frequency data were arcsin transformed before regression analysis. In order to test if the same regression relationship might fit data from both days, we combined the data from days 9 and 15, and conducted multiple linear regression (MLR) with zooplankton biomass (geometric means), a binary dummy variable for time and an interaction term for these two as independent variables. This last term was tested for significance to see if there really was a timerelated change in the quantitative response to zooplankton density between days 9 and 15 .

\section{Results}

General development of zooplankton and chlorophyll a

During the course of the experiment, mesozooplankton gradients were established with abundances

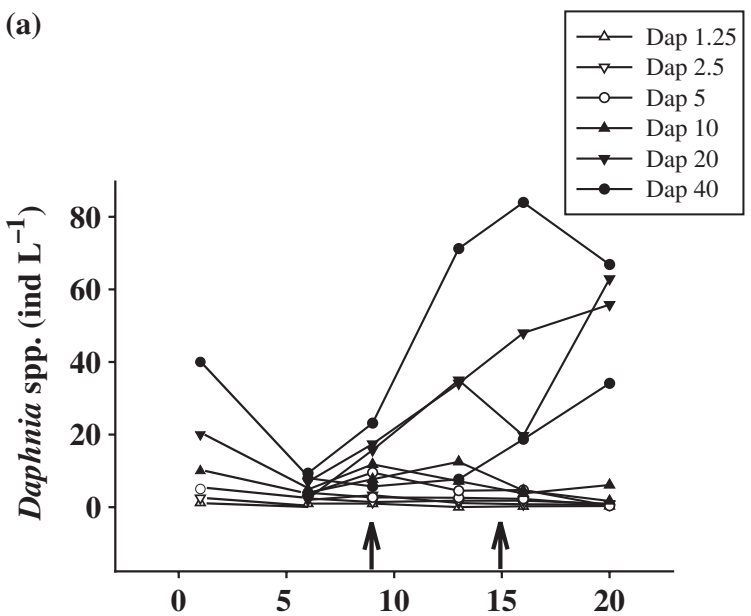

(b)

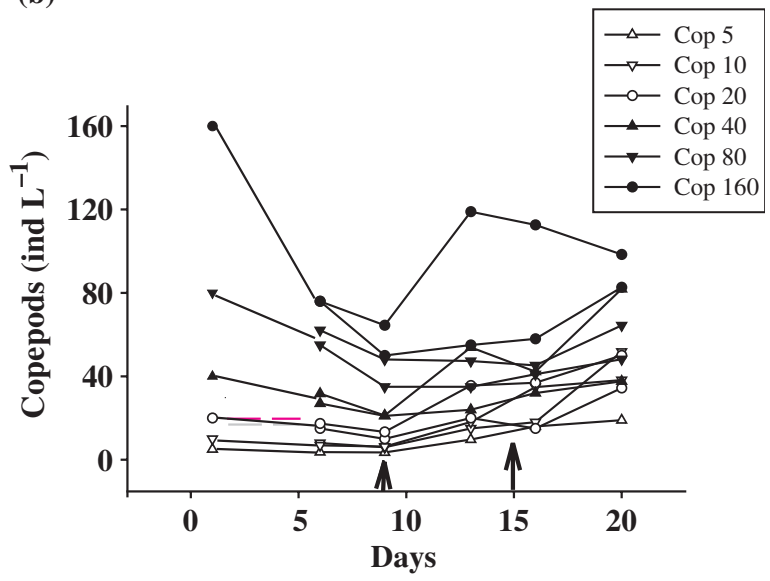

Fig. 1 Zooplankton development (individuals per litre) in Daphnia enclosures (a) and copepod enclosures (b) in the course of the experiment. The first data point of each plot represents the calculated nominal seeding density of the different treatments and was not determined by sample counts. The two selected sampling dates are marked by arrows. 
mostly lower than the calculated seeding densities. Daphnia densities showed a distinct gradient with a strong population increase in the higher density treatments in the second half of the experiment (Fig. 1a). The Daphnia biomass gradient after 9 days ranged between 0 and $155 \mu \mathrm{g}$ dry weight (DW) $\mathrm{L}^{-1}$ (here and thereafter as geometric means, see above), while that after 15 days varied between 0.3 and $489 \mu \mathrm{g}$ DW L ${ }^{-1}$. The copepod gradient persisted more constantly in the course of the experimental period, with a less intense population increase in the highest density treatment (Fig. 1b). Here analogous biomass values were $0-584 \mu \mathrm{g} \mathrm{DW} \mathrm{L}{ }^{-1}$ on day 9 and 2.4$683 \mu \mathrm{g}$ DW L ${ }^{-1}$ on day 15 , respectively.

The date for the first in-depth analysis, performed at day 9, was chosen according to the analysis reported by Sommer et al. (2001, 2003b) and was mainly based on the zooplankton development. Both zooplankton gradients were well established and showed an overlap in their biomass range. However, the population densities, particularly in the Daphnia enclosures, were lower than expected from the calculated seeding densities (mean nine individuals per litre, range 1-23 individuals per litre). Therefore, day 15 was chosen as a second time point for in-depth analysis, where zooplankton gradients were still distinct with increased zooplankton numbers in highest density treatments (Daphnia: mean 16.9 individuals per litre, range $0.2-80.8$ individuals per litre) and thus a wider biomass range. Sommer et al. (2001, $2003 b)$ reported that contamination of copepod enclosures with Daphnia occurred towards the end of the experiment. Detailed zooplankton analysis revealed a marked increase of Daphnia in copepod enclosures after day 16 . Up to then, contaminating Daphnia were mostly small juvenile stages. Daphnia biomass calculated from length measurements of selected samples using the length-biomass regression in Bottrell et al. (1976) indicated a comparably small biomass contribution of Daphnia to total mesozooplankton biomass in the copepod enclosures with a mean value of $11.2 \%$.

As zooplankton were sampled with a $50-\mu \mathrm{m}$ net, rotifers (Keratella sp.) were not quantitatively measured. Rotifers show generally low abundances in summer (Fussmann, 1996) and were monitored roughly together with zooplankton counts and Utermöhl counts of Lugol samples. Only in control enclosures (after 15 days) without Daphnia or
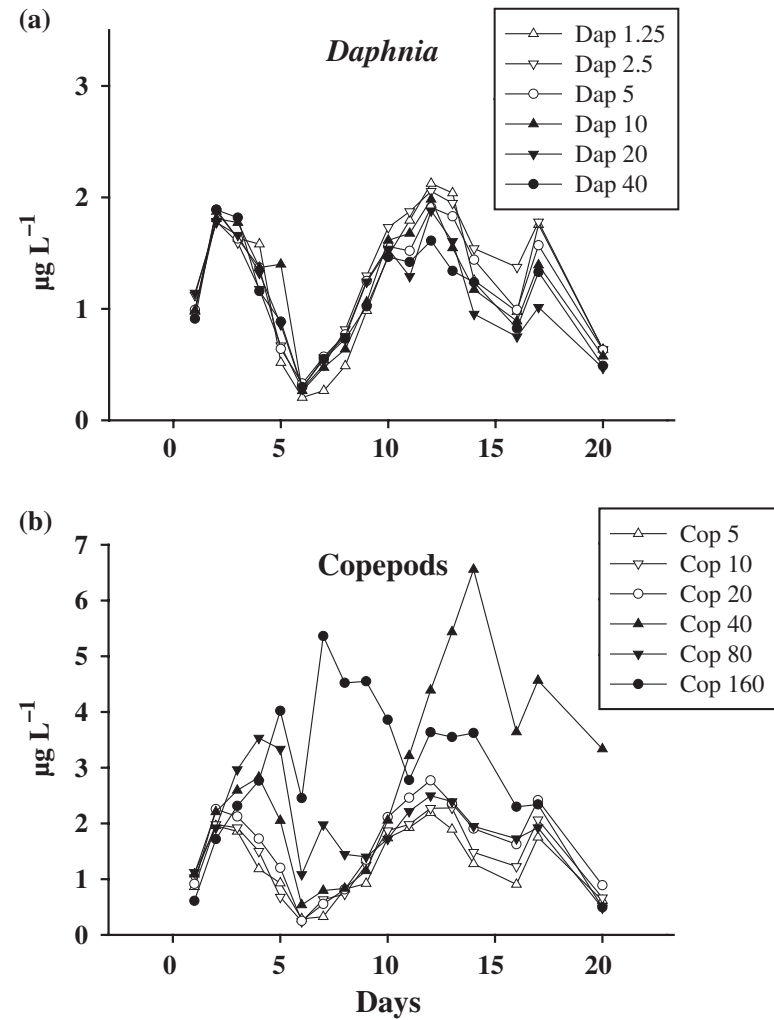

Fig. 2 Chlorophyll $a$ concentrations $\left(\mu \mathrm{g} \mathrm{L}^{-1}\right.$ ) shown in Daphnia enclosures (a) and copepod enclosures (b) in the course of the experiment as mean of two enclosures per treatment.

copepods were estimated rotifer densities high, ranging from 600 to 1200 individuals per litre. Rotifers like Keratella sp. can strongly reduce ciliate growth rate because of direct predation and mechanical interference (Arndt, 1993; Weisse \& Frahm, 2002). Therefore, those two mesocosms were not included in the regression analysis for day 15.

Chlorophyll $a$-values in the enclosures (Fig. 2) were around $1 \mu \mathrm{g} \mathrm{L}^{-1}$ on day 1 and reached maxima of around $6.5 \mu \mathrm{g} \mathrm{L}^{-1}$ (cop 40 treatment). Compared with copepod treatments, chlorophyll-values were consistently lower in Daphnia treatments throughout the experimental period and varied between 0.5 and $2.5 \mu \mathrm{g} \mathrm{L}{ }^{-1}$.

Impact of mesozooplankton on populations of protists and bacteria

Daphnia treatments. Four main ciliate groups (Oligotrichida, Prostomatida, Scuticociliatida, Haptorida) were discriminated besides a small proportion (on 
average $3.2-5.4 \%$ ) of other and undetermined forms. Nanociliates $<20 \mu \mathrm{m}$ mainly comprised small prostomatids like Urotricha and Balanion, while the medium-sized ciliates $(20-40 \mu \mathrm{m})$ were found to be mainly oligotrich forms such as Halteria spp., but also Urotricha spp., scuticociliates like Histiobalantium and haptorids like Askenasia. Ciliates $>40 \mu \mathrm{m}$ consisted mainly of large oligotrichs (e.g. Rimostrombidium lacustris), large prostomatids and raptorial forms like Lagynophrya sp.

On day 9 a slight decrease in all size classes of ciliates with increasing Daphnia abundance was registered, but only the reduction of nanociliates was statistically significant (Fig. 3a, Table 1). A more pronounced impact became apparent on day 15 (Fig. 3b), when Daphnia densities had also reached higher values. However, MLR revealed that only the absolute level of values (intercept) changed significantly because of higher Daphnia biomass (Table 1), indicating no real time-related effect (regression slope not significantly different) of Daphnia grazing impact on ciliates. The abundance of ciliates had strongly decreased compared with day 9 and declined fivefold from lowest to highest Daphnia biomass. Only in lowdensity Daphnia enclosures (dap 1.25, 2.5 and 5) did higher ciliate numbers remain (in total 9-23 cells $\mathrm{mL}^{-1}$ ) which consisted mainly of species $<20 \mu \mathrm{m}(57-78 \%)$. These significantly declined with increasing Daphnia biomass $(P<0.05$, see Table 1$)$.

There was a decreasing but not significant trend in heterotrophic nanoflagellate (HNF) abundances $\left(2.7 \times 10^{3}\right.$ in dap 2.5 to $0.3 \times 10^{3}$ cells $\mathrm{mL}^{-1}$ in dap 40) on day 9 (Fig. 3a). Phototrophic nanoflagellates remained mostly $<1 \times 10^{3}$ cells $\mathrm{mL}^{-1}$. On day 15 (Fig. $3 \mathrm{~b}$ ), due to increased Daphnia biomass and not to timerelated grazing effects (time $\times$ biomass not significant in MLR), the decline of HNF and AMNF was significant $(P<0.05)$ and nanoflagellate concentrations were reduced below $1 \times 10^{3} \mathrm{~mL}^{-1}$ at highest Daphnia densities. Phototrophic nanoflagellates consisted mainly of cells $<5 \mu \mathrm{m}$ with Chrysochromulina sp. and cryptomonads as the dominant taxa.

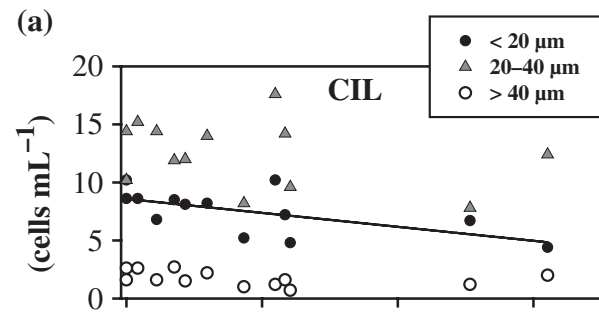

(b)
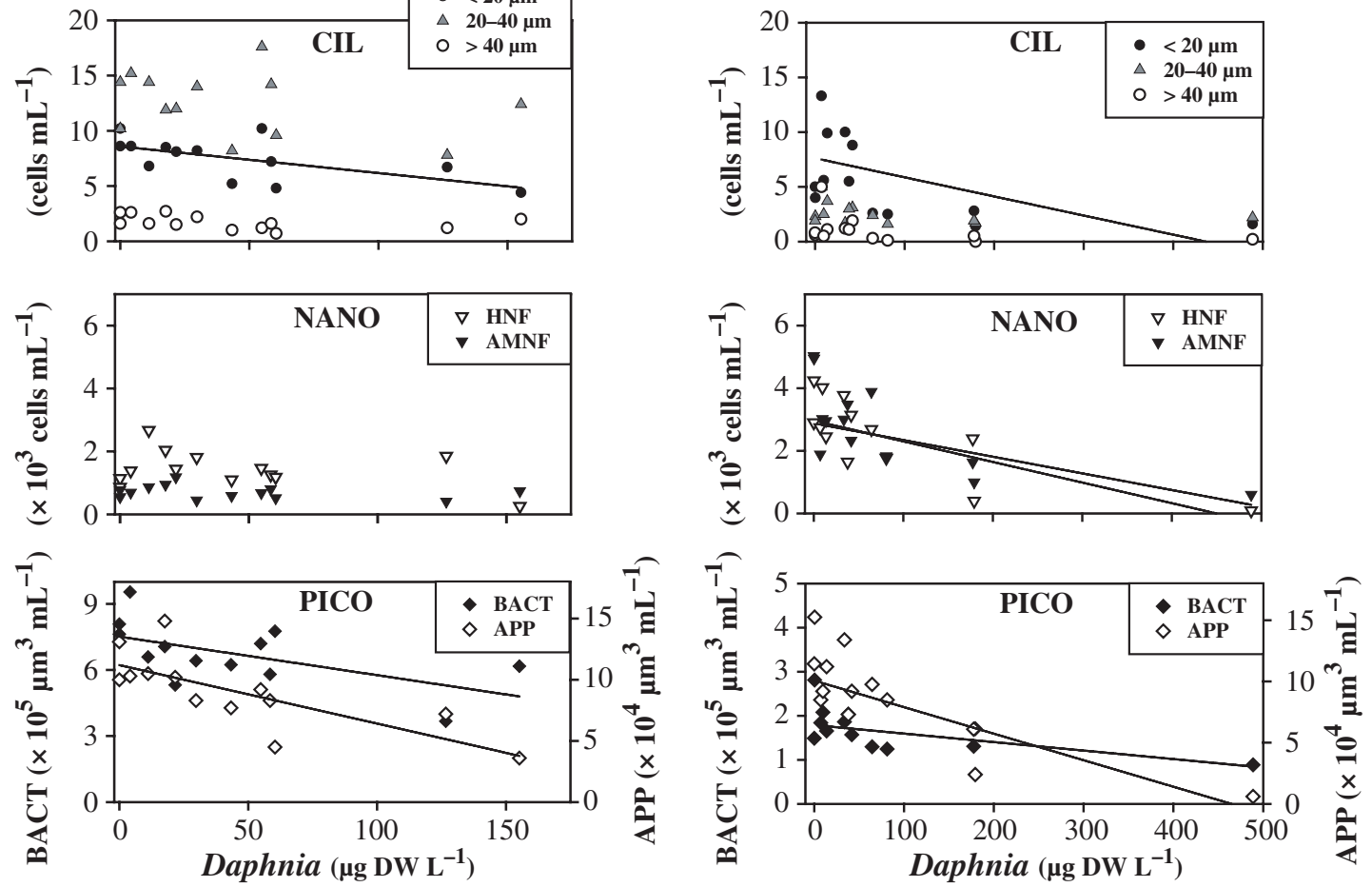

Fig. 3 Impact of Daphnia biomass (geometric mean, $\mu \mathrm{g} \mathrm{DW} \mathrm{L} \mathrm{L}^{-1}$ ) on abundances of ciliates (CIL, upper graph), hetero- and auto-/ mixotrophic nanoflagellates (HNF, AMNF, middle) and on biovolumes of bacteria (BACT, bottom) and autotrophic picoplankton (APP, Synechococcus) for days 9 (a) and 15 (b). Significant regression equations can be obtained from Table 1. In (b) controls were excluded from regression analysis. 
Table 1 Results of regression analyses of Daphnia impact (biomass, geometric mean) on different parameters. Only significant regression equations $(P<0.05$, see figures) are shown together with the net impact (negative or positive). Significant $(P<0.05)$ multiple regression results with time $(+)$ as independent variable are indicated (i.e. significantly different $y$-intercept). There was no significant result with an interaction term of time and biomass as independent variable (i.e. significantly different slope, $*$, see Table 2 )

\begin{tabular}{|c|c|c|c|c|c|c|c|c|c|}
\hline \multirow[b]{3}{*}{ Dependent variable $(y)$} & \multirow[b]{3}{*}{ MLR } & \multicolumn{8}{|c|}{ Daphnia } \\
\hline & & \multicolumn{4}{|c|}{ Day 9} & \multicolumn{4}{|c|}{ Day 15} \\
\hline & & $r^{2}$ & $P$ & Regression equation & Impact & $r^{2}$ & $P$ & Regression equation & Impact \\
\hline Ciliates, $<20 \mu \mathrm{m}$ & & 0.38 & 0.025 & $y=8.579-0.024 x$ & Neg. & 0.37 & 0.048 & $y=7.618-0.018 x$ & Neg. \\
\hline Ciliates, $>20-40 \mu \mathrm{m}$ & + & & n.s. & & & & n.s. & & \\
\hline Ciliates, total & + & & n.s. & & & & n.s. & & \\
\hline$\%$ Prostomatid ciliates & & 0.58 & 0.003 & $y=0.730-0.001 x$ & Neg. & & n.s. & & \\
\hline$\%$ Oligotrich ciliates & & 0.45 & 0.013 & $y=0.914+0.0004 x$ & Pos. & & n.s. & & \\
\hline HNF & + & & n.s. & & & 0.56 & 0.008 & $y=2.960-0.007 x$ & Neg. \\
\hline AMNF & + & & n.s. & & & 0.53 & 0.011 & $y=2.877-0.005 x$ & Neg. \\
\hline APP biovolume & & 0.57 & 0.003 & $y=11.120-0.048 x$ & Neg. & 0.69 & 0.002 & $y=10.068-0.022 x$ & Neg. \\
\hline Bacterial biovolume & + & 0.34 & 0.036 & $y=7.514-0.018 x$ & Neg. & 0.54 & 0.010 & $y=1.788-0.002 x$ & Neg. \\
\hline Specific ${ }^{3} \mathrm{H}$-thy incorporation & + & & n.s. & & & & n.s. & & \\
\hline Total ${ }^{3} \mathrm{H}$-thy incorporation & + & & n.s. & & & 0.59 & 0.009 & $y=28.623-0.033 x$ & Neg. \\
\hline Specific protease turnover rate & & & n.s. & & & & n.s. & & \\
\hline Total protease turnover rate & & 0.67 & 0.044 & $y=8.009-0.010 x$ & Neg. & & n.s. & & \\
\hline Specific protease, $V_{\max }$ & + & & n.s. & & & & n.s. & & \\
\hline Total protease, $V_{\max }$ & & & n.s. & & & & n.s. & & \\
\hline
\end{tabular}

AMNF, auto and mixotrophic nanoflagellates; APP, autotrophic picoplankton; HNF, heterotrophic nanoflagellates; Neg., negative; Pos., positive; n.s., not significant.

A Rhodomonas sp. of around $10 \mu \mathrm{m}$ in length was the predominant autotrophic nanoflagellate under most intense Daphnia grazing.

Autotrophic picoplankton, mainly Synechococcuslike cells with a mean length of $1.42 \mu \mathrm{m}$ and a mean cell volume of $0.65 \mu \mathrm{m}^{3}$, showed a significantly linear biovolume decrease $(P<0.05)$ with increasing Daphnia density at both sampling dates (Fig. 3). Compared with this, the decrease in biovolume of heterotrophic bacteria along the zooplankton gradient was less intense but significant on both days. Both bacteria and APP decreased in abundance from the first to the second sampling date (average concentrations of bacteria declined from 5.70 to $1.84 \times 10^{6} \mathrm{~mL}^{-1}$, those of APP from 1.39 to $1.21 \times 10^{5} \mathrm{~mL}^{-1}$ ). Maximal picoplankton values were measured in the controls, where ciliate numbers were very low but HNF abundances relatively high. Furthermore, compared with enclosures with the highest copepod densities (mean cell volume of bacteria $0.12 \mu \mathrm{m}^{3}$, not shown in graph), Daphnia grazing resulted in a reduced mean bacterial cell volume of $0.08 \mu \mathrm{m}^{3}$.

Summarising the observed effects of Daphnia treatments, it became apparent that a higher Daphnia biomass was necessary to cause strong reductions in micro-, nano- and picoplankton. This reduction along the biomass gradient was more pronounced for ciliates and nanoflagellates than for bacteria.

Copepod treatments. In copepod enclosures the ciliate community showed a differential response to exposure to copepod grazing as was apparent in the analyses of day 9 (Fig. 4a). The total number of ciliates was highest without and with low zooplankton densities (19-28 ciliates $\mathrm{mL}^{-1}$ ) but then decreased strongly with increasing copepod density. Intermediate-sized ciliates $(20-40 \mu \mathrm{m})$ were especially affected and declined significantly $(P<0.05)$ with increasing copepod density. Nanociliates, on the other hand, increased and reached abundances of up to 16 cells $\mathrm{mL}^{-1}$ under high copepod abundance. These shifts in size distribution of the ciliate community were accompanied by a shift in the taxonomic composition from oligotrichs to small prostomatids (mainly Urotricha, Balanion) (Table 2). On day 15 (Fig. 4b), ciliate numbers had already declined in all copepod bags and only nanociliates showed a marginally significant $(0.05<P<0.10)$ relationship with the copepod gradient. Only in treatments with the lowest copepod density retained high abundances of 
(a)
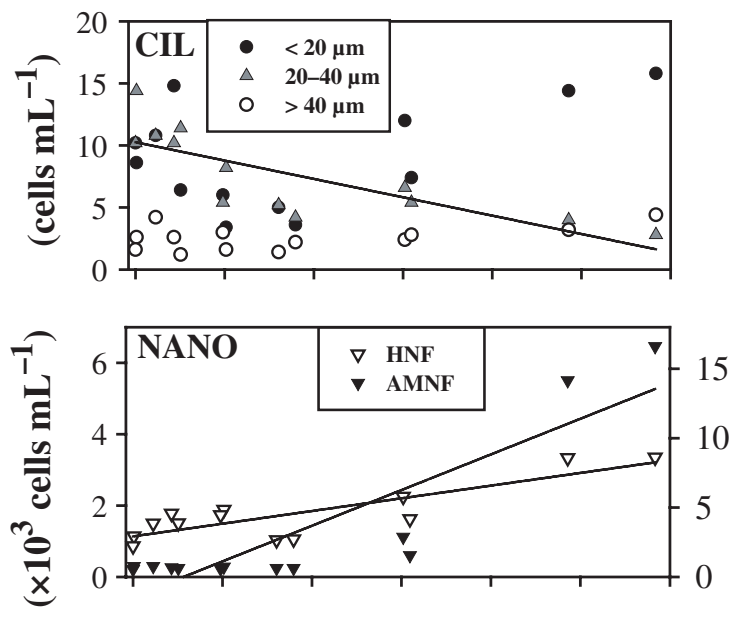

T

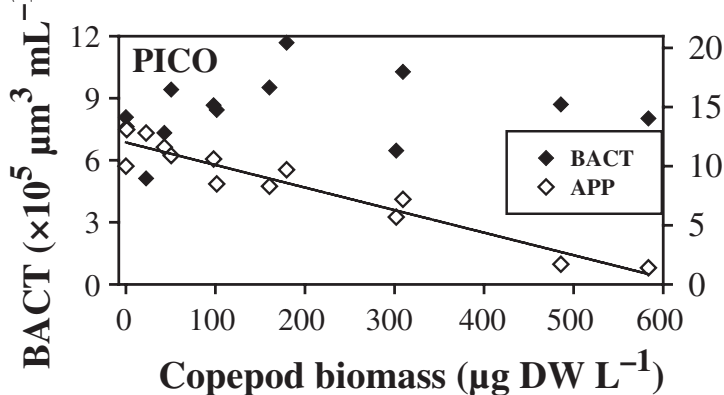

(b)
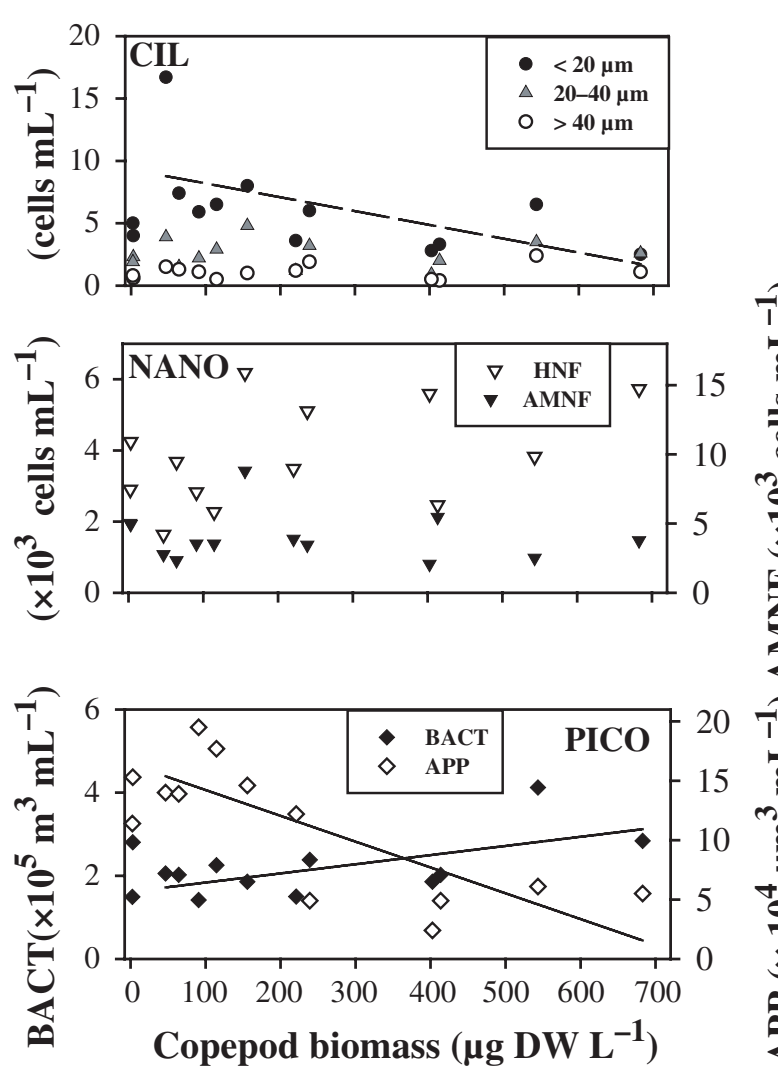

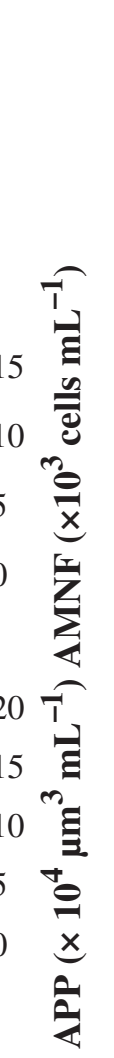

Fig. 4 Impact of copepod biomass (geometric mean $\mu \mathrm{g}$ DW $\mathrm{L}^{-1}$ ) on abundances of ciliates (CIL, upper graph), hetero- and auto-/ mixotrophic nanoflagellates (HNF, AMNF, middle) and on biovolumes of bacteria (BACT, bottom) and autotrophic picoplankton (APP,Synechococcus) for days 9 (a) and 15 (b). Significant regression equations can be obtained from Table 2. In (b) controls were excluded from regression analysis.

ciliates (22 cells $\mathrm{mL}^{-1}$ ), consisting mainly of nanociliates. In contrast to Daphnia treatments, MLR analysis suggested a true dynamical time-related grazing effect of copepods on nanociliates and ciliates $20-40 \mu \mathrm{m}$ in size (Table 2, significant time $\times$ biomass interaction term).

Heterotrophic and phototrophic nanoflagellates showed a strong and significant $(P<0.001)$ increase in abundance along the copepod gradient on day 9 (Fig. 4a). The population incline was more than twofold in the case of HNF whereas phototrophic nanoflagellates increased more than twentyfold at the highest copepod densities, with Chrysochromulina sp. the dominant taxon. On day 15, high concentrations of HNF (up to $6.2 \times 10^{3}$ cells $\mathrm{mL}^{-1}$ ) were found in most copepod treatments with no significant relationship to zooplankton biomass (Fig. 4b). MLR analysis yielded significant time-scale grazing effects on both HNF and AMNF with respect to the $y$-intercept and also for the regression slope in the case of AMNF (Table 2).

Within the picoplankton fraction, APP and heterotrophic bacteria responded differently on day 9 (Fig. 4a). Biovolume of APP decreased significantly with increasing copepod density $(P<0.001)$, whereas bacteria remained relatively constant. Bacterial biovolume varied between 5.1 and $11.7 \times 10^{5} \mu \mathrm{m}^{3} \mathrm{~mL}^{-1}$ with a peak in intermediate copepod density treatments. A differential response in picoplankton, including a decrease in APP and an increase in heterotrophic bacteria $(P<0.05)$, along the zooplankton density gradient was noted also on day 15 (Fig. $4 \mathrm{~b})$. Biovolume of APP ranged between 2.4 and $19.5 \times 10^{4} \mu \mathrm{m}^{3} \mathrm{~mL}^{-1}$ and decreased significantly with increasing copepod density $(P<0.05)$. The range of bacterial biovolume $\left(1.4-4.1 \times 10^{5} \mu \mathrm{m}^{3} \mathrm{~mL}^{-1}\right)$ on day 15 was much lower compared with day 9, but still above values found in Daphnia treatments and with 
Table 2 Results of regression analyses of copepod impact (biomass, geometric mean) on different parameters. Only significant regression equations $(P<0.05$, see figures) are shown together with the net impact (negative or positive). Significant $(P<0.05)$ multiple regression results with time $(+)$ and an interaction term of time and biomass $\left(^{*}\right)$ as independent variables are indicated

\begin{tabular}{|c|c|c|c|c|c|c|c|c|c|}
\hline \multirow[b]{3}{*}{ Dependent variable $(y)$} & \multirow[b]{3}{*}{ MLR } & \multicolumn{8}{|c|}{ Copepods } \\
\hline & & \multicolumn{4}{|c|}{ Day 9} & \multicolumn{4}{|c|}{ Day 15} \\
\hline & & $r^{2}$ & $P$ & Regression equation & Impact & $r^{2}$ & $P$ & Regression equation & Impact \\
\hline Ciliates, $<20 \mu \mathrm{m}$ & $*$ & & n.s. & & & 0.35 & 0.053 & $y=9.288-0.011 x$ & Neg. \\
\hline Ciliates, $>20-40 \mu \mathrm{m}$ & $+*$ & 0.63 & 0.001 & $y=10.258-0.015 x$ & Neg. & & n.s. & & \\
\hline Ciliates, total & & & n.s. & & & & n.s. & & \\
\hline$\%$ Prostomatid ciliates & & & n.s. & & & & n.s. & & \\
\hline$\%$ Oligotrich ciliates & $+*$ & 0.33 & 0.040 & $y=0.916-0.0001 x$ & Neg. & & n.s. & & \\
\hline $\mathrm{HNF}$ & + & 0.71 & 0.000 & $y=1.136+0.004 x$ & Pos. & & n.s. & & \\
\hline AMNF & $+*$ & 0.78 & $<0.0001$ & $y=-1.451+0.026 x$ & Pos. & & n.s. & & \\
\hline APP biovolume & + & 0.92 & $<0.0001$ & $y=12.010-0.019 x$ & Neg. & 0.61 & 0.005 & $y=16.390-0.022 x$ & Neg. \\
\hline Bacterial biovolume & + & & n.s. & & & 0.39 & 0.040 & $y=1.617+0.002 x$ & Pos. \\
\hline Specific ${ }^{3} \mathrm{H}$-thy incorporation & + & & n.s. & & & & n.s. & & \\
\hline Total ${ }^{3} \mathrm{H}$-thy incorporation & & & n.s. & & & 0.51 & 0.014 & $y=23.992+0.035 x$ & Pos. \\
\hline Specific protease turnover rate & + & 0.82 & 0.012 & $y=1.128+0.003 x$ & Pos. & & n.s. & & \\
\hline Total protease turnover rate & & 0.89 & 0.005 & $y=7.432+0.014 x$ & Pos. & & n.s. & & \\
\hline Specific protease, $V_{\max }$ & & 0.79 & 0.017 & $y=26.415+0.065 x$ & Pos. & & n.s. & & \\
\hline Total protease, $V_{\max }$ & & 0.85 & 0.010 & $y=173.836+0.302 x$ & Pos. & & n.s. & & \\
\hline
\end{tabular}

AMNF, auto and mixotrophic nanoflagellates; APP, autotrophic picoplankton; HNF, heterotrophic nanoflagellates; Neg., negative; Pos., positive; n.s., not significant.

highest values at maximal copepod densities. On day 15 , the mean volume of bacterial cells also increased significantly (not shown in graph). Here, the biovolume of cells $>2 \mu \mathrm{m}$ in length ranged from 18 to $33 \times 10^{3} \mu^{3} \mathrm{~mL}^{-1}$ in cop160 treatments, thereby differing considerably from values found in dap 40 treatments $\left(0-6 \times 10^{3} \mu \mathrm{m}^{3} \mathrm{~mL}^{-1}\right)$. Filamentous bacteria $(>5 \mu \mathrm{m})$ generally were of minor importance (around $6 \times 10^{3}$ cells $\mathrm{mL}^{-1}$ in cop160, not shown in graph), but still almost twice as high as in enclosures with the highest Daphnia biomass.

To summarise, selective copepod grazing resulted in a reduction of intermediate-sized ciliates and in a strong increase in nanoflagellates accompanied by a significant decrease in APP, but no significant response in heterotrophic bacteria. Persistent copepod grazing further reduced ciliate densities, raised the level of nanoplankton and caused an increasing trend in bacterial biovolume and cell size along the copepod gradient.

\section{Impact of mesozooplankton on bacterial community composition}

The DGGE profile of enclosures with Daphnia and copepods revealed 20 different OTUs of bacteria on day 9 (Fig. 5a). The highest number of OTUs (19) was found in treatments without zooplankton $(0$ $\mathrm{ZP})$, in the others the number of OTUs varied between 8 and 16. The enclosures deviated slightly from the lake situation on day 9 with respect to number, position and intensity of bands. Results obtained from a UPGMA cluster analysis of a distance matrix using only the presence and absence of bands did not show any distinct grouping patterns or separation of Daphnia and copepod treatments on day 9 (Fig. 5b). Also when including relative DGGE band intensities, no treatment coupled clustering of OTU composition could be observed (not shown).

After 15 days the situation had changed and an analysis of the DGGE profiles using the presence and absence of bands clearly revealed a clustering of OTUs according to the zooplankton treatments (Fig.5c,d). Even within the Daphnia and copepod treatments the DGGE patterns of low and high zooplankton density treatments were clustering together. When taking band intensity into account, an even stronger grouping and less similarity of treatments were observed (not shown). Still 20 different OTUs were found in total, 13 in Daphnia and 15 OTUs in copepod treatments. Three of these appeared 
(a)
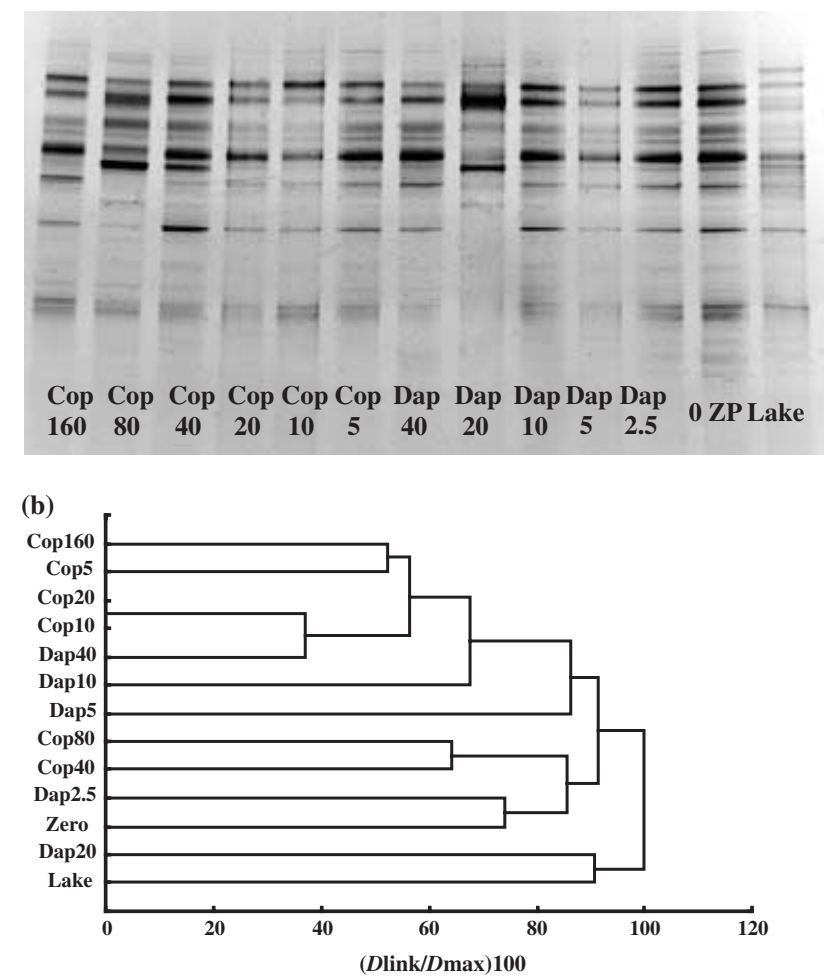

(c)

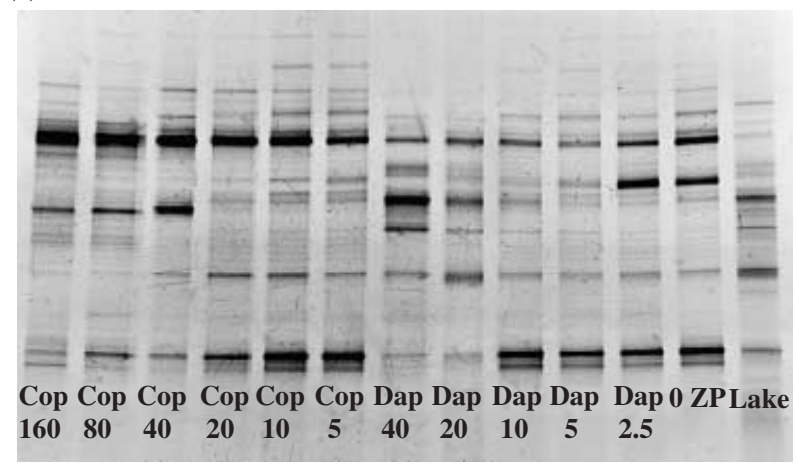

(d)

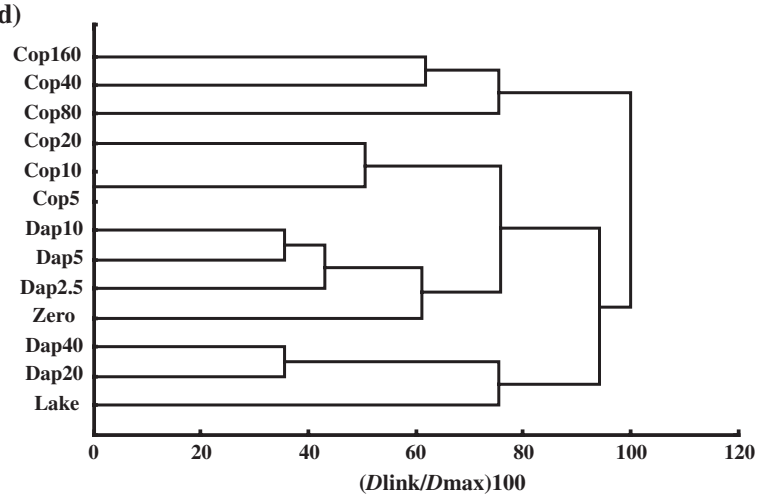

Fig. 5 Denaturing gradient gel electrophoresis (DGGE) gel image obtained for day 9 (a) and day 15 (c) and dendrograms (b) derived from UPGMA cluster analysis of a matrix that takes into account the presence and absence of bands for day 9 (b) and day 15 (d). Clustering is expressed as relative dissimilarity of a linkage compared with the maximal dissimilarity $\left[\left(D_{\text {link }} / D_{\text {max }}\right) \times 100\right)$.

exclusively with Daphnia whereas five OTUs were copepod-specific. The DGGE patterns of the lake sample as well as the $0 \mathrm{ZP}$ enclosure were more closely linked to the Daphnia treatments.

\section{Mesozooplankton impact on bacterial production and activity}

Bacterial production showed a strong scatter and a significant correlation was found neither in total nor in cell-specific incorporation (data not shown) along the Daphnia biomass gradient on day 8 (Fig. 6a). Maximal values of ${ }^{3} \mathrm{H}$-thymidine $\left(50-56 \mathrm{pmol} \mathrm{L}^{-1} \mathrm{~h}^{-1}\right.$ ) and leucine $\left(0.54-0.58 \mathrm{nmol} \mathrm{L}{ }^{-1} \mathrm{~h}^{-1}\right)$ incorporation corresponded to bacterial doubling times of 36 to $45 \mathrm{~h}$. Nevertheless, the activity patterns of protease revealed a significant trend along the Daphnia gradient (Fig. 6a), but only with respect to substrate turnover rates (TR, range $5.2-6.3 \mathrm{nmol} \mathrm{L}^{-1} \mathrm{~h}^{-1}$ ) and not to the maximal substrate hydrolysis rates $\left(V_{\max }\right.$ range $124-140 \mathrm{nmol} \mathrm{L}^{-1} \mathrm{~h}^{-1}$ ).
On day 15 , bacterial production was still high at low Daphnia biomass values $\left(0-80 \mu \mathrm{g} \mathrm{DW} \mathrm{L}{ }^{-1}\right)$ but then clearly declined along the Daphnia gradient $(P<0.05$ for ${ }^{3} \mathrm{H}$-thymidine), which resembles the observed pattern in bacterial biovolume (Fig. 6b). Exoenzyme activity on day 15 showed a strong decrease in both the turnover rate and maximal hydrolysis velocity of protease with increasing Daphnia density and thus was congruent with the decline in bacterial biovolume and ${ }^{3} \mathrm{H}$-thymidine incorporation (Fig. 6b).

Nor did bacterial production in copepod enclosures correlate significantly with mesozooplankton density on day 8 (Fig. 7a). Maximal values of ${ }^{3} \mathrm{H}$-thymidine incorporation (up to $60 \mathrm{pmol} \mathrm{L}^{-1} \mathrm{~h}^{-1}$ ) and ${ }^{3} \mathrm{H}$-leucine incorporation (up to $0.60 \mathrm{nmol} \mathrm{L}^{-1} \mathrm{~h}^{-1}$ ) suggest bacterial doubling times of 34 and $37 \mathrm{~h}$, respectively. In contrast, protease activity showed a significant increase in $V_{\max }(P<0.05)$ and turnover rate $(P<0.05)$ along the copepod gradient on day 9 . Six days later, the patterns of bacterial production and activity clearly followed the trend in bacterial biovolume with 
(a)

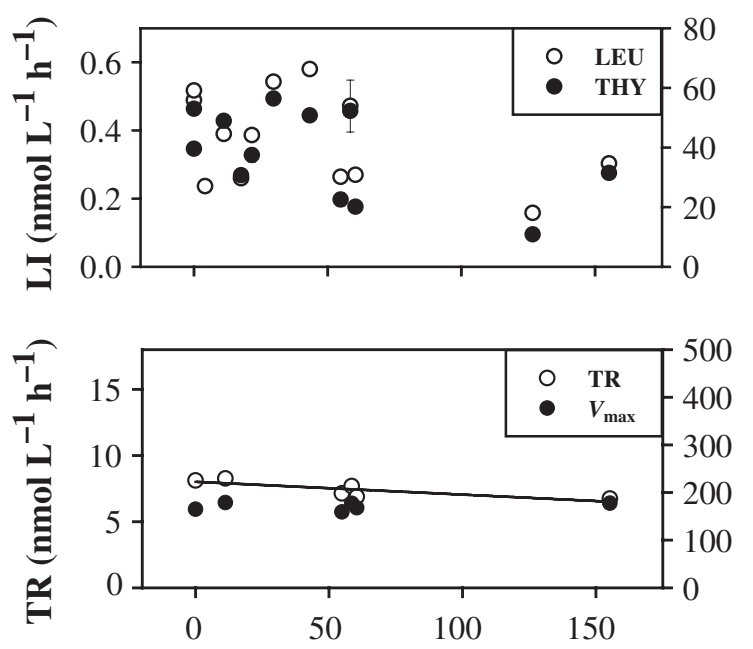

Daphnia biomass DW $\left(\mu \mathrm{g} \mathrm{L}^{-1}\right)$ (b)

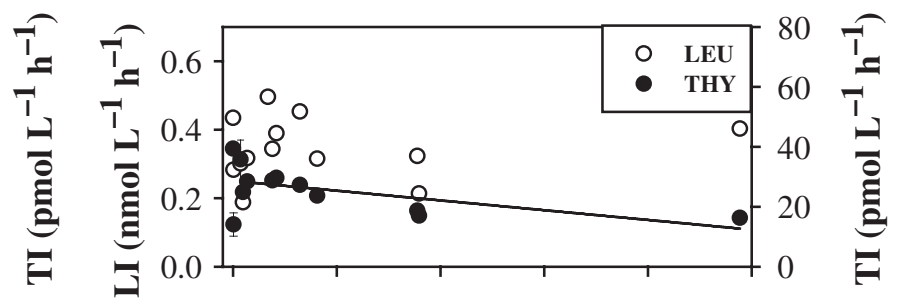

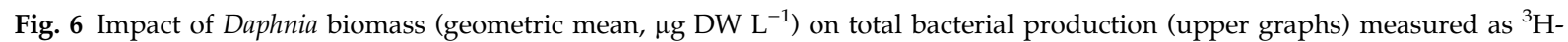
thymidine $\left(\mathrm{pmol} \mathrm{L}{ }^{-1} \mathrm{~h}^{-1}\right)$ and ${ }^{3} \mathrm{H}$-leucine incorporation $\left(\mathrm{nmol} \mathrm{L}^{-1} \mathrm{~h}^{-1}\right)$ and on substrate hydrolysis rates of the bacterial exoenzyme protease (lower graphs) shown as turnover rates (TR) and maximal velocities $\left(V_{\max }\right)$ of hydrolysis $\left(\mathrm{nmol} \mathrm{L} \mathrm{L}^{-1} \mathrm{~h}^{-1}\right)$ on days 8 (a) and 15 (b). Significant regressions equations can be obtained from Table 1. In (b) controls were excluded from regression analysis.

(a)
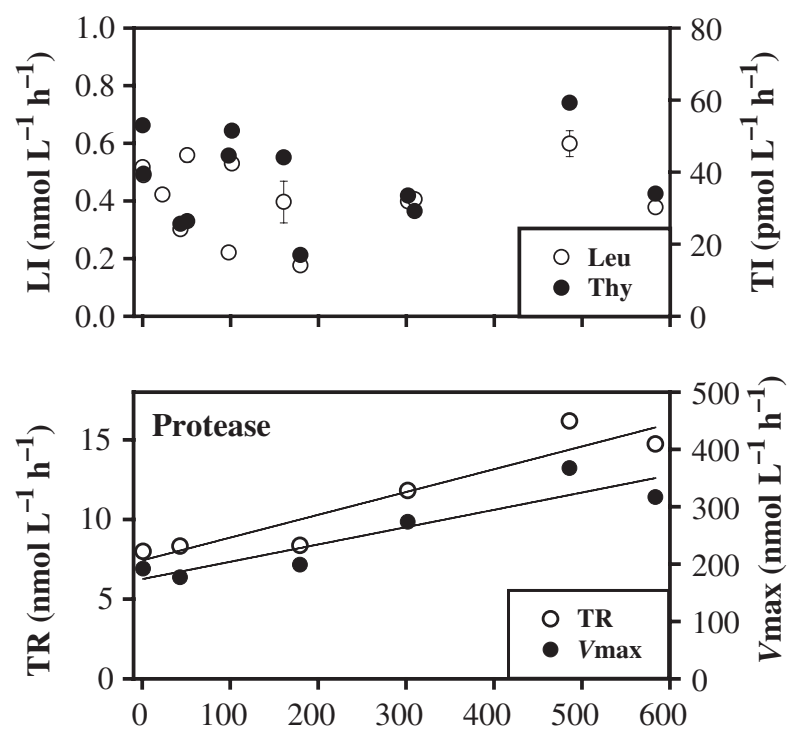

Copepod biomass $\left(\mu \mathrm{g} \mathrm{DW} \mathrm{L}^{-1}\right)$ (b)
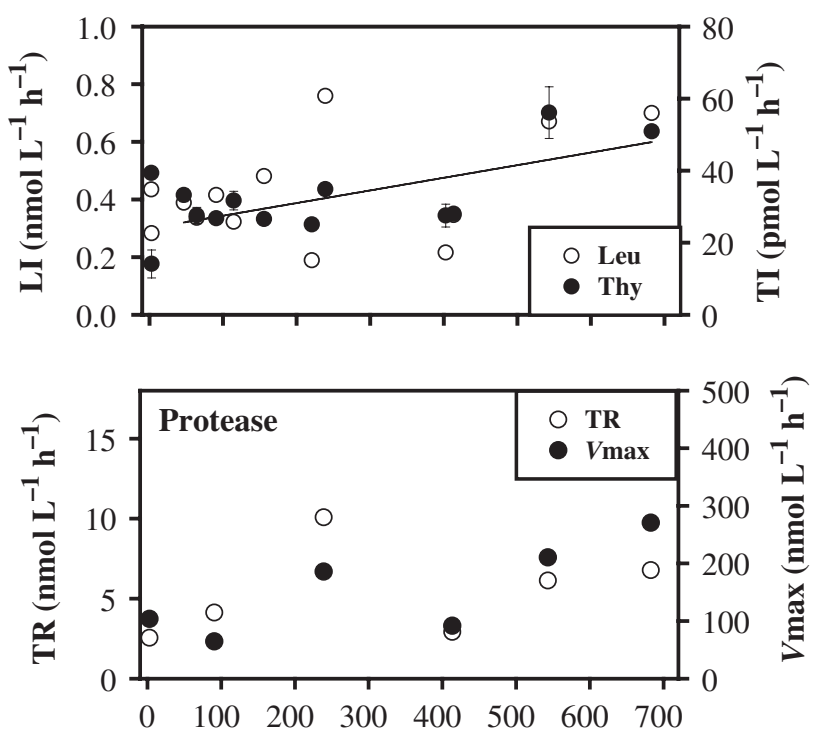

Copepod biomass ( $\left.\mu \mathrm{g} \mathrm{DW} \mathrm{L}^{-1}\right)$

Fig. 7 Impact of copepod biomass (geometric mean, $\mu \mathrm{g} \mathrm{DW} \mathrm{L}^{-1}$ ) on total bacterial production (upper graphs) measured as ${ }^{3} \mathrm{H}-$ thymidine (pmol L $\mathrm{L}^{-1} \mathrm{~h}^{-1}$ ) and ${ }^{3} \mathrm{H}$-leucine incorporation $\left(\mathrm{nmol} \mathrm{L} \mathrm{L}^{-1} \mathrm{~h}^{-1}\right.$ ) and on substrate hydrolysis rates of the bacterial exoenzyme protease (lower graphs) shown as turnover rates (TR) and maximal velocities $\left(V_{\max }\right)$ of hydrolysis $\left(\mathrm{nmol} \mathrm{L} \mathrm{L}^{-1} \mathrm{~h}^{-1}\right)$ on days $8(\mathrm{a})$ and 15 (b). Significant regression equations can be obtained from Table 2. In (b) controls were excluded from regression analysis.

a significant $(P<0.05)$ increase in ${ }^{3} \mathrm{H}$-thymidine incorporation along the copepod gradient (Fig. $7 b$ ). Protease $V_{\max }$ was within the same range as on day 9 and still increased with copepod density $(P=0.066)$, the increase in turnover rate was not significant anymore $(P=0.52 ;$ Fig. $7 \mathrm{~b})$. In general, mean enzyme 
(a)

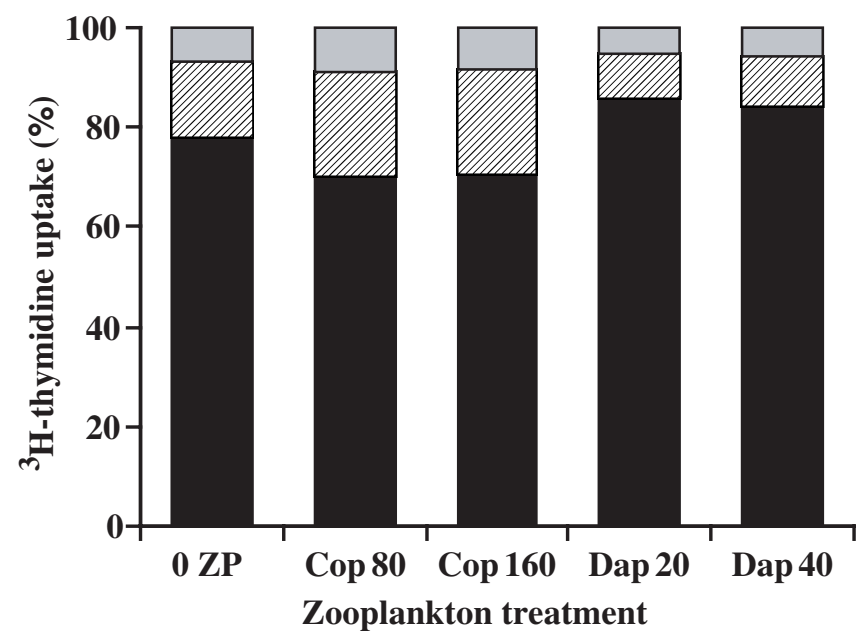

(b)

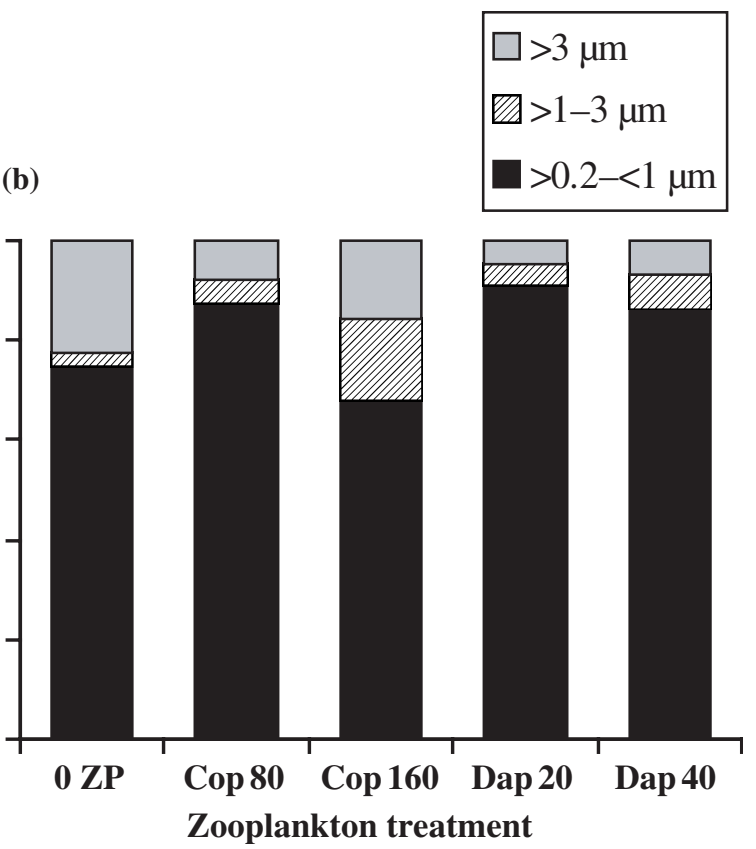

Fig. 8 Size-fractionated ${ }^{3} \mathrm{H}$-thymidine uptake in five enclosure treatments (0 ZP, cop 80, cop 160, dap 20, dap 40) at days 10 (a) and 15 (b). The relative contributions of three bacterial size classes $(>0.2-<1,1-3$ and $>3 \mu \mathrm{m})$ to total ${ }^{3} \mathrm{H}$-thymidine uptake are shown. Values are mean of three replicates. The mean coefficient of variations of each fraction were $0.10(>0.2-<1 \mu \mathrm{m}), 0.06(1-3 \mu \mathrm{m})$ and 0.13 (>3 $\mu \mathrm{m})$.

activity values for protease were found to be $20-62 \%$ higher in copepod compared with Daphnia treatments.

Parallel to the increase in total bacterial biovolume the proportion of cells $>1 \mu \mathrm{m}$ increased from $32 \%$ in controls to $52 \%$ in the enclosures with highest copepod biomass (data not shown in graph). This shift in bacterial size distribution was also evident from size-fractionated ${ }^{3} \mathrm{H}$-thymidine uptake (Fig. 8). It revealed that in high-density copepod enclosures (cop 80 , cop 160 on day 10, cop 160 on day 15) as well as in control enclosures without metazooplankton large bacteria $(>3 \mu \mathrm{m})$ contributed with a relatively high proportion (up to $22 \%$ in $0 \mathrm{ZP}$, Fig. $8 \mathrm{~b}$ ) to total ${ }^{3} \mathrm{H}$-thymidine uptake. In contrast, in Daphnia enclosures the smallest bacterial size fraction $>0.2$ to $<1 \mu \mathrm{m}$ was responsible for $84-91 \%$ of the total bacterial uptake.

\section{Discussion}

While many previous studies used small-scale microcosms for food web experiments, here the effects of different mesozooplankton guilds were analysed on a larger scale by using enclosures of a sufficiently large volume to provide more reliable predictions of whole-lake phenomena (Sarnelle, 1997). Furthermore, this mesocosm experiment was based on a gradient design of mesozooplankton concentrations and so allowed a finer resolution of critical densities, which are able to cause significant responses in the microbial components. The zooplankton concentrations which developed in the enclosures were, with the exception of the highest densities at the end of the experiment, within the range reported from the study lake (Fussmann, 1996). Also, the observed protozoan and bacterial concentrations in the different enclosures, as well as bacterial growth rates, were within the range found normally in this mesotrophic lake (Jürgens, Arndt \& Rothhaupt, 1994). Therefore, the extent of the observed responses can be considered realistic for the lake situation. The chosen time-points for a detailed analysis of the microbial community structure (9 and 15 days of experimental duration) corresponded to approximately three to eight generations of bacteria and of the different functional groups of protozoans. Previous experiments at this study site suggest that this scale is appropriate to demonstrate both direct short-term predation impacts of the metazooplankton, cascading effects via protozoans to bacteria as well as bacterial adaptations towards changes in predation pressure (Jürgens et al., 1994). 
Contrasting effects of Daphnia and copepods on protozooplankton

Studies on the effect of cladocerans and copepods on populations of protozoa in lakes have mostly shown significant impacts of both crustacean groups on ciliates and other microplankton (Adrian \& Schneider-Olt, 1999; Burns \& Schallenberg, 2001a; Yoshida et al., 2001). Our experiment also found that both zooplankton guilds affected the ciliate community. By the second time point higher Daphnia densities had strongly reduced the total ciliate abundance, thereby confirming other studies, which have proved that Daphnia exerts efficient top-down control on ciliate assemblages (Wickham, 1998; Burns \& Schallenberg, 2001a). For ciliates it is known that their species and size composition influences their vulnerability to Daphnia and calanoid copepods (Burns \& Gilbert, 1993; Jack \& Gilbert, 1993; Wiackowski et al., 1994). This is mainly because of the fact that a number of species have jumping behaviour that reduces their vulnerability to predators (Gilbert, 1994). In our experiments also, medium-sized Oligotrichida with bristles for jumping, such as Halteria spp. (or Pelagohalteria spp.) remained in the highest Daphnia density treatments.

In contrast to Daphnia, differential and selective grazing of copepods induced a shift in size and composition of the ciliate assemblage. The ciliate sizefraction $20-40 \mu \mathrm{m}$ was most efficiently reduced by copepod predation. This fraction comprised important oligotrich taxa such as Strobilidium, Halteria and Pelagohalteria, which are voracious grazers on picoand nanoplankton (Šimek et al., 2000). In contrast, small prostomatid ciliates (Urotricha spp., Balanion sp.) increased in abundance. Similar shifts towards prostomatid nanociliates were also found in a hypertrophic lake during high abundance of cyclopoid copepods (Jürgens, Skibbe \& Jeppesen, 1999; Hansen, 2000). Yoshida et al. (2001) also found copepod size selectivity with Eudiaptomus feeding mainly on larger algae $(>20 \mu \mathrm{m})$ and microzooplankton in mesotrophic Lake Biwa.

Whereas the overall impact on ciliates differed only in qualitative aspects between daphnids and copepods, the mesozooplankton groups showed clearly opposite effects on the abundance of nanoflagellates: increasing Daphnia biomass resulted in a significant reduction of HNF abundance but an increase in copepods led to an increase in HNF density. A likely explanation is that copepods impact on nanoplankton only indirectly via ciliates whereas daphnids exert a well-known direct grazing pressure on nanoplankton (Jürgens, 1994). It is probable that a combination of ciliate and Daphnia grazing accounted for low abundance levels of nanoflagellates along the Daphnia gradient on day 9, whereas 6 days later, in spite of strongly reduced ciliate grazing, higher Daphnia densities caused a significant reduction of nanoflagellates. This would be consistent with previous studies showing that HNF are within the optimal prey size spectrum of filterfeeding cladocerans, and that HNF populations are suppressed when Daphnia are abundant (e.g. Porter et al., 1988; Jürgens, 1994; Pace \& Vaqué, 1994).

Nanoflagellates showed a remarkable two- (HNF) to twentyfold (AMNF) increase with increasing copepod biomass. This is most probably because of the fact that ciliates, particularly oligotrichs, are highly efficient feeders on nanoplankton (Cleven, 1996; Šimek et al., 2000a) and HNF are increasingly released from ciliate grazing pressure with the expansion of copepod biomass. Copepods themselves are generally thought to be relatively inefficient feeders on nanoplankton, although this seems to be more valid for cyclopoid than for calanoid species (Jürgens et al., 1996; Burns \& Schallenberg, 2001a). The significant positive relationship between HNF and copepods did not persist until the second time-point of in-depth analysis (Fig. 4b). However, here HNF were already at higher concentrations and might have become increasingly food-limited because of the decline in picoplankton and the development of less edible bacteria (indicated by an increasing proportion of larger bacteria).

The contrasting feeding modes of Daphnia and copepods thus differentially impacted on the protozoan community. Daphnia seemed to top-down control nearly the whole protozooplankton, from large ciliates to nanoflagellates. Copepods, instead, efficiently and selectively preyed upon $20-40 \mu \mathrm{m}$-sized ciliates, thereby triggering a trophic cascade to the nanoplankton level, enabling high HNF numbers, which potentially affect the picoplankton (see also Sommer et al., 2003b). Similar to other studies (Burns \& Schallenberg, 2001a), ciliates turned out to be key links in the copepod-mediated trophic cascade down to nano- and possibly picoplankton, thereby linking the microbial and the classic food chain in lakes. 


\section{Direct and indirect mesozooplankton effects on planktonic bacteria}

We focused in this study on short-term reactions of bacterial biomass, activity and genetic diversity to an altered zooplankton-grazing regime. Within the picoplankton, heterotrophic bacteria and autotrophic picoplankton (mainly Synechococcus cells) reacted differently. APP strongly decreased in both gradients of crustacean mesozooplankton, in Daphnia enclosures presumably caused by direct Daphnia grazing, in copepod treatments likely because of high protist grazing pressure. The larger cell volume of APP (mean $0.65 \mu^{3}$ ) compared with heterotrophic bacteria (range $0.08-0.16 \mu \mathrm{m}^{3}$ ) probably makes them vulnerable to different grazers.

Compared with micro- and nanoplankton, the biomass of heterotrophic bacteria showed a less pronounced response to mesozooplankton manipulation in this experiment and appeared to be buffered against zooplankton density alteration. The mean total bacterial biovolume over all Daphnia enclosures was slightly lower than in control and copepod enclosures. While a Daphnia biomass gradient between 0 and $155 \mu \mathrm{g} \mathrm{DW} \mathrm{L}{ }^{-1}$ apparently caused a significant decrease in total bacterial biovolume (day 9, Fig. 3a), here a comparable biomass range of copepods had only little impact (Fig. 4). Higher Daphnia densities, however, caused a strong reduction of bacterial biovolume (Fig. 3b), thereby supporting other studies that demonstrated control of bacterial populations in lakes by Daphnia and other filter-feeding cladocerans (e.g. Riemann, 1985; Pace et al., 1990; Vaqué \& Pace, 1992). Strong top-down control of planktonic bacteria by Daphnia seems to prevail when they achieve higher densities in meso- to eutrophic lakes and ponds whereas comparable studies in more oligotrophic systems with lower Daphnia densities revealed no effect or only weak effects on bacterioplankton (Pace \& Funke, 1991; Brett et al., 1994). Apart from differences in absolute Daphnia densities, a very weak impact of Daphnia on bacterial communities in oligotrophic systems can be explained by the fact, that the small and often inactive bacteria normally predominating in these systems are not affected, as the filter mesh-size of cladocerans retains bacteria above a certain size limit (approximately $>0.5-0.7 \mu \mathrm{m}$, Brendelberger, 1991). This means that larger, actively growing bacteria are particularly influenced. This size-selective bacterial grazing by daphnids was probably also responsible for the observed decrease in mean bacterial size and the decline in bacterial production and activity with increasing Daphnia biomass (Fig. 6). Similar observations were reported from extended periods of Daphnia maxima ('clearwater phase') in lakes (Güde, 1988; Jeppesen et al., 1992; Christoffersen et al., 1993).

Estimated bacterial grazing mortality was of the same order of magnitude at both ends of the gradient, under strong HNF (dap 1.25 and 2.5) and Daphnia (dap 40) grazing, respectively. The high concentrations of HNF in copepod enclosures resulted in a general decline of bacteria on day 15 . There was, however, no significant relationship between $\mathrm{HNF}$ and bacteria along the copepod gradient and bacterial biovolume even increased with increasing copepod densities (and hence also increasing HNF concentrations) (Fig. 4b). Previous mesocosm experiments revealed that increased predation pressure by HNF could result in the compensation of grazing mortality by the development of inedible morphotypes of bacteria, e.g. filamentous forms and aggregates (Jürgens et al., 1994, Šimek et al., 1999). Although we did not observe a mass development of resistant filaments, as occurred in a previous experiment in the same lake (Jürgens et al., 1994), the shift towards larger bacterial cells in mesocosms with low ciliate and high HNF abundances (controls, cop 160, see also Fig. 8) and the occurrence of a higher proportion of filaments are indications of those grazing-resistant forms. A positive correlation between copepod populations and the abundance of filamentous bacteria has been observed also in eutrophic shallow lakes (Jürgens \& Jeppesen, 2000) and interpreted as a trophic cascade in which copepod predation on ciliates enhances HNF grazing pressure on bacteria and thereby the development of resistant morphotypes. However, the extent to which filamentous bacteria can develop seems to be influenced also by other factors such as nutrient availability. Besides morphological resistance other mechanisms of grazing-resistance such as motility and physicochemical surface properties can also be of importance for stabilising bacterial biomass (reviewed by Jürgens \& Matz, 2002).

The difference in bacterial composition between copepod- and Daphnia-dominated treatments 
confirms other enclosure experiments which showed that a change in bacterivory from Daphnia to protist grazing results more in taxonomic shifts rather than in differences in bacterial biomass (Langenheder \& Jürgens, 2001). Such changes in prey composition without changes in prey biomass, mainly because of differences in predator feeding mode and prey vulnerabilities, were termed a 'cryptic trophic cascade' by Tessier \& Woodruff (2002). However, the taxonomic level response of the bacterial community to an altered grazing regime seemed to take place rather slowly. Only at the second time-point of analysis, did the clustering of bacterial OTUs and also the occurrence and contribution of certain OTUs show a clear grouping according to mesozooplankton treatments (Fig. 5d). High copepod density treatments (cop 40, cop 80, cop 160) clustered together suggesting the existence of a distinct HNF-grazing adapted bacterial community.

The increasing bacterial activity and production, as seen from thymidine and leucine incorporation as well as from exoenzymatic activity (Fig. 7) along the copepod gradient points to stimulation of bacteria by protist grazing. The level of protease activity in copepod treatments was considerably higher than in Daphnia treatments. This can be attributed to an increase in bacterial biomass as well as enhanced bacterial substrate demand. Furthermore, protease excretions of HNF and AMNF can contribute to the extracellular enzyme pool (Karner, Ferrierpages \& Rassoulzadegan, 1994). Aquatic bacteria are subject to a range of potential impact modes, and could also have been affected by varying substrate supply because of differences in algal communities and different metazoan and protozoan dissolved organic carbon (DOC) release (sloppy feeding, excretion, Nagata, 2000). Nevertheless, we think that the different predation impacts by metazoans (Daphnia bags) and protozoans (copepod bags) were probably major factors shaping the structure of the bacterial assemblages in this experiment.

While the existence of clear trophic cascades has been shown between various components in aquatic systems, most often from fish via zooplankton to phytoplankton (Carpenter, Kitchell \& Hodgson, 1985; Pace et al., 1999), there is considerably less knowledge about the extent of cascading effects on heterotrophic microorganisms, and bacterial assemblages in particular are difficult to integrate into food web patterns. We found clear differences with respect to mesozooplankton effects in Daphnia versus copepod-dominated communities on the microbial food web structure. Our results confirm the general concept that microbial food webs differ markedly between systems with and without abundant Daphnia populations (Stockner \& Porter, 1988; Pace et al., 1990; Riemann \& Christoffersen, 1993). The fate of bacterial production in freshwater systems is determined by the composition of higher trophic levels and the dominant selective pressure can be exerted by protist or Daphnia grazing. Our study additionally revealed that copepod-dominated zooplankton can trigger a clear predatory cascade involving strong and opposing fluctuations in microand nanoplankton.

Our results also confirm previous studies that strong effects of planktonic food web structure are mainly found for populations of ciliates and flagellates. The regulation of bacterioplankton seems to function quite differently, judged from the weak effects of an altered grazer community on bacteria in enclosure experiments (Pace \& Funke, 1991; Wickham, 1998; Adrian et al., 2001) and whole lake studies (Pace \& Cole, 1996). Also in this study the heterotrophic bacterial assemblage proved quite stable, reacted slowly towards an altered grazing regime and showed strongest biomass responses in treatments with lowest and highest mesozooplankton biomass. Weak food web effects on planktonic bacteria have been interpreted as truncation of the trophic cascade at the level of protozoans (Pace \& Funke, 1991; Wickham, 1998). However, by considering several bacterial response variables, such as bacterial community composition and activity, it became obvious in our experiment that significant effects did occurr at the bacterial level. Evidence for trophic effects on bacterial composition comes also from other studies, which considered bacterial community structure (Cochran-Stafira \& von Ende, 1998; Šimek et al., 1999; Langenheder \& Jürgens, 2001). These results confirm the importance of heterogeneity within bacterial communities and imply that true trophic cascades in the community sense (Strong, 1992) are the exception rather than the rule for planktonic bacteria. Instead, there presumably occur, in response to altered biological interactions, shifts 
and adaptations within bacterial assemblages, which involve changes in species composition, phenotypic characters and physiological activities.

\section{Acknowledgments}

The experiments were sponsored by Deutsche Forschungsgemeinschaft (Grant JU367/4-1). Technical support from the staff of the Max-Planck-Institut für Limnologie in Plön and the Institut für Meereskunde in Kiel is gratefully acknowledged. We are especially grateful to Ulrich Sommer, Colleen Jamieson, Thomas Hansen, Ilka Dankert, Regine Koppe, Cornelia Burghardt, Sonja Dembeck and Claes Becker for help in the field and in the laboratory. We also would like to thank W. Lampert for supporting this work.

\section{References}

Adrian R. \& Schneider-Olt B. (1999) Top-down effects of crustacean zooplankton on pelagic microorganisms in a mesotrophic lake. Journal of Plankton Research, 21, 2175-2190.

Adrian R., Wickham S.A. \& Butler N.M. (2001) Trophic interactions between zooplankton and the microbial community in contrasting food webs: the epilimnion and deep chlorophyll maximum of a mesotrophic lake. Aquatic Microbial Ecology, 24, 83-97.

Arndt H. (1993) Rotifers as predators on components of the microbial web (bacteria, heterotrophic flagellates, ciliates) - a review. Hydrobiologia, 255/256, 231-246.

Bell R.T. (1993) Estimating production of heterotrophic bacterioplankton via incorporation of tritiated thymidine. In: Handbook of Methods in Aquatic Microbial Ecology (Eds P.F. Kemp, B.F. Sherr, E.B. Sherr \& J.J. Cole), pp. 495-503. Lewis Publishers, Boca Raton, FL.

Beutler M., Wiltshire K.H., Meyer B., Moldaenke C., Lüring C., Meyerhöfer M., Hansen U.-P \& Dau H. (2002) A fluorometric method for the differentiation of algal populations in vivo and in situ. Photosynthesis Research, 72, 39-53.

Björnsen P.K. (1986) Automatic determination of bacterioplankton biomass by image analysis. Applied and Environmental Microbiology, 51, 1199-1204.

Bottrell H.H., Duncan A., Gliwicz Z.M., Grygierek E., Herzig A., Hillbricht-Ilkowska A., Kurasawa H., Larsson P. \& Weglenska T. (1976) A review of some problems in zooplankton production studies. Norwegian Journal of Zoology, 24, 419-456.
Brendelberger H. (1991) Filter mesh size of cladocerans predicts retention efficiency for bacteria. Limnology and Oceanography, 36, 884-894.

Brett M.T., Wiackowski K., Lubnow F.S., Müller-Solger A., Elser J.J. \& Goldman C.R. (1994) Species-dependent effects of zooplankton on planktonic ecosystem processes in Castle Lake, California. Ecology, 75, 22432254.

Burns C.W. \& Gilbert J.J. (1993) Predation on ciliates by freshwater calanoid copepods: rates of predation and relative vulnerabilities of prey. Freshwater Biology, 30, 377-393.

Burns C.W. \& Schallenberg M. (1996) Relative impacts of copepods, cladocerans and nutrients on the microbial food web of a mesotrophic lake. Journal of Plankton Research, 18, 683-714.

Burns C.W. \& Schallenberg M. (1998) Impacts of nutrients and zooplankton on the microbial food web of an ultra-oligotrophic lake. Journal of Plankton Research, 20, 1501-1525.

Burns C.W. \& Schallenberg M. (2001a) Calanoid copepods versus cladocerans: consumer effects on protozoa in lakes of different trophic status. Limnology and Oceanography, 46, 1558-1565.

Burns C.W. \& Schallenberg M. (2001b) Short-term impacts of nutrients, Daphnia, and copepods on microbial food-webs of an oligotrophic and eutrophic lake. New Zealand Journal of Marine and Freshwater Research, 35, 695-710

Carpenter S.R., Kitchell J.F. \& Hodgson J.R. (1985) Cascading trophic interactions and lake productivity. BioScience, 35, 635-639.

Carrick H.J., Fahnenstiel G.L., Stoermer E.F. \& Wetzel R.G. (1991) The importance of zooplankton-protozoan trophic couplings in Lake Michigan. Limnology and Oceanography, 36, 1335-1345.

Christoffersen K., Riemann B., Klysner A. \& Søndergaard M. (1993) Potential role of fish predation and natural populations of zooplankton in structuring a plankton community in eutrophic lake water. Limnology and Oceanography, 38, 561-573.

Cleven E.-J. (1996) Indirectly fluorescently labelled flagellates (IFLF): a tool to estimate the predation on freeliving heterotrophic flagellates. Journal of Plankton Research, 18, 429-442.

Cochran-Stafira D.L. \& von Ende C.N. (1998) Integrating bacteria into food webs - studies with Sarracenia purpurea inquilines. Ecology, 79, 880-898.

Cotner J.B. \& Biddanda B.A. (2002) Small players, large role: microbial influence on biogeochemical processes in pelagic aquatic ecosystems. Ecosystems, 5, 105-121. 
DeMott W.R. (1988) Discrimination between algae and artificial particles by freshwater and marine copepods. Limnology and Oceanography, 33, 397-408.

Ducklow H.W., Kirchman D.L. \& Quinby H.L. (1992) Bacterioplankton cell growth and macromolecular synthesis in seawater cultures during the North Atlantic spring phytoplankton bloom. Microbial Ecology, 24, 125-144

Foissner W. \& Berger H. (1996) A user-friendly guide to the ciliates (Protozoa, Ciliophora) commonly used by hydrobiologists as bioindicators in rivers, lakes, and waste waters, with notes on their ecology. Freshwater Biology, 35, 375-482.

Fussmann G. (1996) Die Kontrolle der Rotatorien im Pelagial eines mesotrophen Sees durch Bottom-up und Top-down-Prozesse: Freilandbeobachtungen und Enclosure-Experimente. PhD Thesis. University Kiel, 1996.

Gilbert J.J. (1994) Jumping behavior in the oligotrich ciliates Strobilidium velox and Halteria grandinella, and its significance as a defense against rotifer predators. Microbial Ecology, 27, 189-200.

Gliwicz Z.M. (1980) Filtering rates, food size selection, and feeding rates in cladocerans - another aspect of interspecific competition in filter-feeding zooplankton. In: Evolution and ecology of zooplankton communities (Ed. W.C. Kerfoot), pp. 282-291. University Press of New England.

Gocke K. (1977) Comparison of methods for determining the turnover times of dissolved organic compounds. Marine Biology, 42, 131-142.

Güde H. (1988) Direct and indirect influences of crustacean zooplankton on bacterioplankton of Lake Constance. Hydrobiologia, 159, 63-73.

Hansen A.M. (2000) Response of ciliates and Cryptomonas to the spring cohort of a cyclopoid copepod in a shallow hypereutrophic lake. Journal of Plankton Research, 22, 185-203.

Hoppe H.-G. (1993) Use of Fluorogenic Model Substrates for Extracellular Enzyme Activity (EEA) Measurement of Bacteria. In: Handbook of Methods in Aquatic Microbial Ecology (Eds P.F. Kemp, B.F. Sherr, E.B. Sherr \& J.J. Cole), pp. 423-431. Lewis Publishers, Boca Raton, FL.

Hoppe H.-G., Giesenhagen H.C. \& Gocke K. (1998) Changing patterns of bacterial substrate decomposition in a eutrophication gradient. Aquatic Microbial Ecology, 15, 1-13.

Jack J.D. \& Gilbert J.J. (1993) Susceptibilities of differentsized ciliates to direct suppression by small and large cladocerans. Freshwater Biology, 29, 19-29.

Jeppesen E., Sortkjaer O., Søndergaard M. \& Erlandsen M. (1992) Impact of a trophic cascade on heterotrophic bacterioplankton production in two shallow fish-manipulated lakes. Archiv für Hydrobiologie Beihefte Ergebnisse der Limnologie, 37, 219-231.

Jürgens K. (1994) Impact of Daphnia on planktonic microbial food webs - a review. Marine Microbial Food Webs, 8, 295-324.

Jürgens K. \& Jeppesen E. (2000) The impact of metazooplankton on the structure of the microbial food web in a shallow, hypertrophic lake. Journal of Plankton Research, 22, 1047-1070.

Jürgens K. \& Matz C. (2002) Predation as a shaping force for the phenotypic and genotypic composition of planktonic bacteria. Antonie van Leeuwenhoek International Journal of General \& Molecular Microbiology, 81, 413-434.

Jürgens K., Arndt H. \& Rothhaupt K.O. (1994) Zooplankton-mediated changes of bacterial community structure. Microbial Ecology, 27, 27-42.

Jürgens K., Wickham S.A., Rothhaupt K.O. \& Santer B. (1996) Feeding rates of macro- and microzooplankton on heterotrophic nanoflagellates. Limnology and Oceanography, 41, 1833-1839.

Jürgens K., Skibbe O. \& Jeppesen E. (1999) Impact of metazooplankton on the composition and population dynamics of planktonic ciliates in a shallow, hypertrophic lake. Aquatic Microbial Ecology, 17, 61-75.

Karner M., Ferrierpages C. \& Rassoulzadegan F. (1994) Phagotrophic nanoflagellates contribute to occurrence of alpha-glucosidase and aminopeptidase in marine environments. Marine Ecology Progress Series, 114, 237244.

Kirchman D.L. (1993) Leucine incorporation as a measure of biomass production by heterotrophic bacteria. In: Handbook of Methods in Aquatic Microbial Ecology (Eds P.F. Kemp, B.F. Sherr, E.B. Sherr \& J.J. Cole), pp. 509-512. Lewis Publishers, Boca Raton, FL.

Lampert W., Fleckner W., Rai H., \& Taylor B.E. (1986) Phytoplankton control by grazing zooplankton: a study on the clear water phase. Limnology and Oceanography, 31, 478-490.

Langenheder S. \& Jürgens K. (2001) Regulation of bacterial biomass and community structure by metazoan and protozoan predation. Limnology and Oceanography, 46, 121-134.

Massana R. Gasol J.M., Björnsen P.K., Blackburn N., Hagström A., Hietanen S., Hygum B.H., Kuparinen J. \& Pedros-Alio C. (1997) Measurement of bacterial size via image analysis of epifluorescence preparations description of an inexpensive system and solutions to some of the most common problems. Scientia Marina, 61, 397-407.

Muyzer G., Brinkhoff T., Nübel U., Santegoeds C., Schäfer H. \& Wawer C. (1998) Denaturing gradient gel electrophoresis (DGGE) in microbial 
ecology. In: Molecular Microbial Ecology Manual 3.4.4. (Eds A.D.L. Akkermans, J.D. vanElsas, and F.J. deBruijn), pp. 1-27. Kluwer Academic Publishers, Dordecht.

Nagata T. (2000) Production mechanisms of Dissolved Organic Matter. In: Microbial Ecology of the Oceans (Ed. D.L. Kirchman), pp. 121-152. Jon Wiley \& Sons, Inc.

Pace M.L. \& Cole J.J. (1996) Regulation of bacteria by resources and predation tested in whole-lake experiments. Limnology and Oceanography, 41, 1448-1460.

Pace M.L. \& Funke E. (1991) Regulation of planktonic microbial communities by nutrients and herbivores. Ecology, 72, 904-914.

Pace M.L. \& Vaqué D. (1994) The importance of Daphnia in determining mortality rates of protozoans and rotifers in lakes. Limnology and Oceanography, 39, 985996.

Pace M.L., McManus G.B. \& Findlay S.E.G. (1990) Planktonic community structure determines the fate of bacterial production in a temperate lake. Limnology and Oceanography, 35, 795-808.

Pace M., Cole J., Carpenter S. \& Kitchell J. (1999) Trophic cascades revealed in diverse ecosystems. Trends in Ecology and Evolution, 14, 483-488.

Paul J. \& Myers B. (1982) Fluorometric determination of DNA in aquatic microorganisms by use of Hoechst 33258. Applied and Environmental Microbiology, 43, 13931399.

Porter K.G., Paerl, H., Hodson R., Pace M., Priscu J., Riemann B., Scavia D. \& Stockner J. (1988) Microbial interactions in lake food webs. In: Complex interactions in lake communities (Ed. S.R. Carpenter), pp. 209-227. Springer-Verlag, New York.

Riemann, B. (1985) Potential importance of fish predation and zooplankton grazing on natural populations of freshwater bacteria. Applied and Environmental Microbiology, 50, 187-193.

Riemann B. \& Christoffersen K. (1993) Microbial trophodynamics in temperate lakes. Marine Microbial Food Webs, 7, 69-100.

Sanders R.W. \& Wickham S.A. (1993) Planktonic protozoa and metazoa: predation, food quality and population control. Marine Microbial Food Webs, 7, 197223.

Sarnelle O. (1993) Herbivore effects on phytoplankton succession in a eutrophic lake. Ecological Monographs, 63, 129-149.

Sarnelle O. (1997) Daphnia effects on microzooplankton comparisons of enclosure and whole-lake responses. Ecology, 78, 913-928.

Schauer M., Massana R. \& Pedros-Alio C. (2000) Spatial differences in bacterioplankton composition along the Catalan coast (NW Mediterranean) assessed by molecular fingerprinting. FEMS Microbioloy Ecology, 33, 51-59.

Šimek K., Kojecka P., Nedoma J., Hartman P., Vrba J. \& Dolan J.R. (1999) Shifts in bacterial community composition associated with different microzooplankton size fractions in a eutrophic reservoir. Limnology and Oceanography, 44, 1634-1644.

Šimek K., Jürgens K., Nedoma J., Comerma M. \& Armengol J. (2000) Ecological role and bacterial grazing of Halteria spp.: small freshwater oligotrichs as dominant pelagic ciliate bacterivores. Aquatic Microbial Ecology, 22, 43-56.

Smits J.D. \& Riemann B. (1988) Calculation of cell production from tritiated thymidine incorporation with freshwater bacteria. Applied and Environmental Microbiology, 54, 2213-2219.

Sommer U., Sommer F. Santer B., Jamieson C., Boersma M., Becker C., Hansen T. (2001) Complementary impact of copepods and cladocerans on phytoplankton. Ecology Letters, 4, 545-550.

Sommer F., Santer B., Jamieson C., Hansen T. \& Sommer U. (2003a) Daphnia population growth but not moulting is a substantial drain for phytoplankton. Freshwater Biology, 48, 67-74.

Sommer U., Sommer F., Santer B., Zöllner E., Jürgens K., Jamieson C., Boersma M. \& Gocke K. (2003b) Daphnia versus copepod impact on summer phytoplankton: functional compensation at both trophic levels. Oecologia, 135, 639-647.

Stockner J.G. \& Porter K.G. (1988) Microbial food webs in freshwater planktonic ecosystems. In: Complex Interactions in Lake Communities (Ed. S.R. Carpenter), pp. 6984. Springer-Verlag, New York.

Strong D. (1992) Are trophic cascades all wet? Differentiation and donor-control in speciose ecosystems. Ecology, 73, 747-754.

Tessier A.J. \& Woodruff P. (2002) Cryptic trophic cascade along a gradient of lake size. Ecology, 83, 1263-1270

Thingstad T.F. \& Lignell R. (1997) Theoretical models for the control of bacterial growth rate, abundance, diversity and carbon demand. Aquatic Microbial Ecology, 13, 19-27.

Vanni M.J. \& Temte J. (1990) Seasonal patterns of grazing and nutrient limitation of phytoplankton in a eutrophic lake. Limnology and Oceanography, 35, 697-709.

Vaqué D. \& Pace M.L. (1992) Grazing on bacteria by flagellates and cladocerans in lakes of contrasting food-web structure. Journal of Plankton Research, 14, 307-321.

Weisse T. \& Frahm A. (2002) Direct and indirect impact of two common rotifer species (Keratella spp.) on two abundant ciliate species (Urotricha furcata, Balanion planctonicum). Freshwater Biology, 47, 53-64. 
Wiackowski K., Brett M.T. \& Goldman C.R. (1994) Differential effects of zooplankton species on ciliate community structure. Limnology and Oceanography, 39, 486-492.

Wickham S.A. (1995) Trophic relations between cyclopoid copepods and ciliated protists: complex interactions link the microbial and classic food webs. Limnology and Oceanography, 40, 1173-1181.

Wickham S.A. (1998) The direct and indirect impact of Daphnia and Cyclops on a freshwater microbial food web. Journal of Plankton Research, 20, 739-755.
Yoshida T., Gurung T.B., Kagami M. \& Urabe J. (2001) Contrasting effects of a cladoceran (Daphnia galeata) and a calanoid copepod (Eodiaptomus japonicus) on algal and microbial plankton in a Japanese lake, Lake Biwa. Oecologia, 129, 602-610.

(Manuscript accepted 22 September 2003) 